\title{
Mükellefler Vergi Artışına Nasıl Tepki Gösterir? Mükelleflerin Sosyal Medyada Vergi Artışına Karşı Gösterdiği Tepkilerin Motivasyon Kaynaklarına İlişkin Nitel Bir Analizi
}

\author{
How Taxpayers React to Tax Increase? A Qualitative Analysis on \\ Motivational Factors towards Tax Increases on Social Media
}

\author{
Recep Yücedoğru ${ }^{1}$ \\ Arınç Boz ${ }^{2}$ \\ Seda Öner ${ }^{3}$ \\ Halil Emre Saygı ${ }^{4}$ \\ Erdem Dibek ${ }^{5}$
}

EMPIRICAL

RESEARCH

\section{ARTICLE INFO}

Submitted : 06.08.2018

Revised : 17.10.2018

Accepted : 26.11.2018

Available : 30.12 .2018

JEL classification:

$\mathrm{H} 24, \mathrm{H} 22, \mathrm{H} 23$

\begin{abstract}
A B S T R A C T
In this study, in order to research taxpayer's motivations towards tax increase some of the concepts which affect taxpayers' reactions of taxation like tax justice, government trust, corruption perception, satisfaction of public services, splurge, patriotism, tax amnesty influence, taxpayers' income, education level, perception of tax administration, justification and opportunism is created as a conceptual framework. In order to create a framework that guides us to understand taxpayer reactions to a tax increase, we took an opportunity of 2017 changes of the
\end{abstract}

Cite this article as: Yücedoğru, R. et all. (2018). "Mükellefler Vergi Artışına Nasıl Tepki Gösterir?: Mükelleflerin Sosyal Medyada Vergi Artışına Karşı Gösterdiği Tepkilerin Motivasyon Kaynaklarına ilişkin Nitel Bir Analizi", International Journal of Public Finance, Vol.3, No.2, pp. 161-192.

1 Assist. Prof. PhD., (ORCID ID: https://orcid.org/0000-0003-4798-9576), Zonguldak Bülent Ecevit University, Faculty of Economics and Administrative Sciences, Department of Public Finance, Turkey, recep.yucedogru@beun.edu.tr

2 Res. Assist. (https://orcid.org/0000-0002-4936-1339), Zonguldak Bülent Ecevit University, Faculty of Economics and Administrative Sciences, Department of Public Finance, Turkey, arincboz@hotmail.com

3 Res. Assist. (https://orcid.org/0000-0001-6462-4144), Zonguldak Bülent Ecevit University, Faculty of Economics and Administrative Sciences, Department of Public Finance, Turkey, sedayilmaz@beun.edu.tr

4 PhD Student, (https://orcid.org/0000-0002-7025-1062), Zonguldak Bülent Ecevit University, Social Sciences Institute, Department of Public Finance, Turkey, h.emresaygi@gmail.com

5 PhD Student, (https://orcid.org/0000-0002-2012-1788), Zonguldak Bülent Ecevit University, Social Sciences Institute, Department of Public Finance, Turkey, dibekerdem@gmail.com 
Yücedoğru, R. et all. (2018). “Mükellefler Vergi Artışına Nasıl Tepki Gösterir?: Motivasyon Kaynaklarına İlişkin Nitel Bir Analizi", International Journal of Public Finance, Vol.3, No.2, pp. 161-192.

Keywords:

Motor Vehicle Tax, Income Tax, Turkey, Qualitative Analysis tax system in motor vehicle tax and the increase of the third bracket of personal income that caused an unprecedented social reaction over social media and press. We focused on the social media reactions that posted on Twitter, one of the most used social media platforms in Turkey, and gathered data from trending topics during the period of 27th of September 2017 and 14th of October 2017. We gathered 20.984 tweets from eleven trending topics. The data were analyzed with thematic analysis. Findings of the analysis showed that government trust is the most common motivation behind reactions and it is followed by tax burden concerns. This research has a unique contribution to the literature as it is the first attempt to categories social media reactions over a tax increase in the Turkish context and it also contributes to international literature.

\section{MAKALE BígGisi \\ Gönderme: 06.08.2018 \\ Düzeltme : 17.10.2018 \\ Kabul : :26.11.2018 \\ Yayın : : 30.12.2018}

JEL Kodu:

$\mathrm{H} 24, \mathrm{H} 22, \mathrm{H} 23$

\section{Anahtar Kelimeler:}

Motorlu Taşıtlar Vergisi, Gelir Vergisi, Türkiye, Nitel Analiz

\section{ÖZET}

Bu çalışmada mükelleflerin vergi artışına yönelik sosyal medyada gösterdikleri tepkilerinin ardındaki faktörler (kaygıları) anlaşılmaya ve kategorize edilmeye çalışılmıştır. Diğer bir değişle bu araştırma mükelleflerin vergi verme davranışlarını etkileyen faktörlerden; vergilemede adalet, devlete duyulan güven, yolsuzluk algısı, kamu hizmetlerden memnuniyet, savurganlık, vatanseverlik, vergi afları, gelir seviyesi, eğitim seviyesi, vergi yönetiminin algısı, rasyonel gerekçelendirme, fırsatçılık gibi literatürde yer bulan faktörlerin vergi artışlarına verilen tepkilerde ne derece etkili olduğunu anlamayı amaçlamıştır. Bu nedenle öncelikle bahsedilen faktörlerin mükelleflerin vergi artışına yönelik tepkilerinin ardındaki motivasyonlarını araştırmak için bir kavramsal çerçeve oluşturulmuştur. Vergi artışına mükelleflerin tepkilerinin anlaşılmasında yardımcı olacak bir çerçeve oluşturmak için, motorlu taşıt vergisinde ve kısmen gelir vergisi tarifesine 2017 yılında getirilen artışı ve bunun sosyal medya üzerinde daha önce görülmemiş bir şekilde oluşan toplumsal tepki nitel veri toplamak için bir fırsata dönüştürülmüştür. Bu sebeple Türkiye'nin en çok kullanılan sosyal medya platformlarından biri olan Twitter'da yayınlanan sosyal medya tepkilerine odaklanılmış ve 27 Eylül 2017 ile 14 Ekim 2017 döneminde trend olan konulardan (hashtag'ler) veri toplanmıştır. On bir trend konudan 20.984 tweet toplanmış ve veriler tematik analiz yöntemi ile incelenmiştir. Analizin bulguları, hükümete güveninin tepkilerin ardındaki en yaygın motivasyon olduğunu ve vergi yükü endişeleriyle özdeşleştiğini göstermiştir. Bu araştırma, literatürde vergi artışı üzerindeki sosyal medya tepkilerini kategorize etmeye yönelik bilebildiğimiz ilk girişim olması nedeni ile uluslararası ve ulusal literatüre katkıda bulunmaktadır.

\section{Giriş}

Sosyal medyanın giderek artan kullanımı ve teknolojinin her an ulaşılabilir olması bireylerin Facebook, Instagram, Twitter gibi sosyal medya platformlarını günlük olarak kullanmalarını ve herhangi bir sosyal olgu karşısında tepkilerini anlık olarak ortaya koyma davranışını da beraberinde getirmiştir. Bu ve bunun gibi tepkiler, günden güne artış göstererek politik tepkileri de beraberinde getirmiştir ve politika yapıcıların 
kararlarını da etkileyebilecek güce ulaşmıştır. Bunun yanında politika yapıcıların da mevcut konumunu korumaları veya geliştirmeleri için sosyal medyada dile getirilen tepkileri göz ardı etmemeleri gerekmektedir. Çalışmamız, 2018 yılı içinde Gelir Vergisi üçüncü diliminin \%27 olan oranının \%30'a çıkartılması ve binek otomobilden alınan Motorlu Taşıtlar Vergisi oranlarında önce \%40, sonra \%25 artış yapılması yönünde hazırlanan ve Türkiye Büyük Millet Meclisi'ne sunulan sağlayan kanun teklifine karşı mükellefler tarafından gösterilen tepkilerin ardındaki motivasyonu etkileyen faktörleri belirlemeyi amaçlamaktadır.

Çalışmanın amacı doğrultusunda, sosyal medya platformlarından biri olan Twitter'da tweet atılarak gösterilen tepkiler değerlendirilmektedir. Twitter'da "Vergi Zammı", "MTV" ve "Gelir Vergisi" etiketleri ile 27 Eylül-14 Ekim 2017 tarihleri arasında atılan tweet'ler, nitel araştırma yöntemi olan tematik analiz yöntemi ile analiz edilmiştir.

\section{Literatür ve Kavramsal Çerçeve}

Vergiler ve zaman içerisinde vergilerde meydana gelebilen artışlar mükelleflerin tepki göstermesine sebep olabildiğinden, devlet-vatandaş ilişkisi açısından önemli bir role sahiptir. Vergilemede adalet algısı, vergi gelirlerini artırma ya da bunların tahsilatı yönünde alınan birtakım kararlar ve yapılan çeşitli yasal düzenlemeler mükelleflerin vergiye uyumunu etkilemektedir. Bu durum vergiyi algılama bakımından mükellefler arasında farklı etkiler oluşmasına sebep olmakta ve vergiye karşı farklı mükellef tepkilerine yol açabilmektedir.

Vergiler, bireylerin kullanabilir gelirinde azalmaya sebep olacağından, kanun koyucunun bireylerin vergilere yönelik oluşan algılarını ve bunların nedenlerini göz önünde bulundurması gerekmektedir. Aksi takdirde, mükelleflerin vergiye gönüllü uyumunun azalmasına yada vergiden kaçınma ve kaçırma davranışının yaygınlaşması muhtemeldir. Vergi, alınmaya başlandığından beri karşılıksız ve cebri olması nedeniyle mükellef tarafından tepki gösterilmesine neden olmuş, bu durum vergiye karşı direnç oluşmasını beraberinde getirmiştir. Vergiler, gerek kamu gelirlerinin önemli bir kısmını oluşturması açından iktisat ve maliyeciler, gerekse mükellefin vergiye tepki göstermesine ve bireylerin kullanabilir gelirini etkileme gücüne sahip olmasından dolayı önem arz etmektedir.

Mükelleflerin vergiye karşı oluşan tepkileri anlamak için maliye literatürü çeşitli faktörlerin bunları tetiklediğini öne sürmüştür. Bu faktörlere bu bölümde değinilecek ve literatürün görüşleri aktarılacak olsa da öncelikle okuyucunun bu faktörleri bütüncül bir göz ile anlayabilmesi için Şekil 1'de kavramsal çerçeve literatürden hareketle ortaya konulmuştur. Bahsedilen kavramlar aşağıdaki gibidir: 


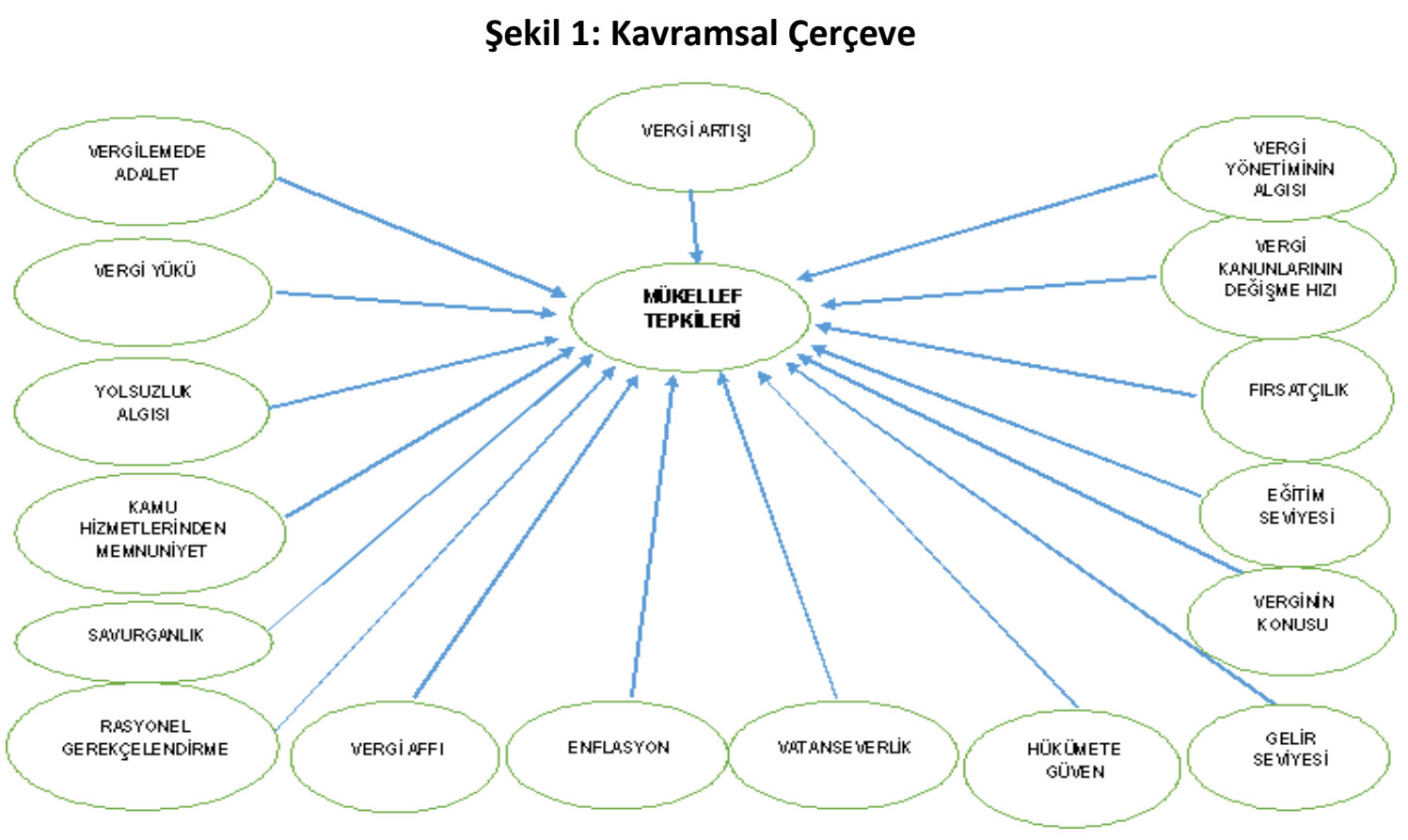

\subsection{Vergilemede Adalet}

Adalet kavramı insanlığın düşünce tarihi boyunca tartışılagelen bir kavram olmuştur. Sokrates'ten bu yana temel olarak iki adalet anlayışından söz edilir (Gök vd. 2013: 270). Denkleştirici adalet, özünde birey özgürlükleri bulunan, herkese eşit davranılan bir adalet anlayışının benimsendiği bir anlayış iken, dağıtıcı adalet özünde eşitlikçi bir zihniyete sahip olan, insanların bazı özelliklerine göre farklı uygulamalara maruz kalabileceğini öne süren bir adalet anlayışıdır (Yereli \& Ata, 2011: 23).

Vergilemede adalet kavramı, ilk çağdan günümüze kadar tartışılagelen ve incelenen bir kavramdır. Devletin oluşumuyla birlikte ortaya çıkan vergileme ve vergilemenin adalet temelli yapılandırılması sorunu günümüzde halen devam etmektedir. Son yıllarda hükümetler, vergilemede adalet ve etkinliği toplumda kabul edilebilir bir düzeyde tutmayı amaçlamaktadırlar (Gök vd., 2013: 270). Vergilemede adalet kavramı ise Adam Smith (1776) 'in "Milletlerin Zenginliği" ile ekonomi literatüründe tartışılmaya başlanmıştır. Geçerliliği bugün de hala muhafaza edilen, Adam Smith'in vergilemenin dört temel ilkesinden ilki, adalet kavramıdır (Şen ve Sağbaş, 2015: 223).

Stiglitz (1988) vergi sisteminin uygulanabilir olmasını beş ana ilkeye bağlamıştır. Bu ilkelerden ilki eşit/adil bir vergi sistemine sahip olmaktır. Bu vergi sistemi yatay ve dikey adaleti sağlamalıdır. Burada bahsedilen yatay adalet aynı ödeme gücüne sahip olanları aynı vergilendirilmesi iken dikey adalet farklı durumlardaki mükelleflerin farklı vergilendirilmesidir. 
Edgeworth (1897: 555), zenginlerin fakirlerle aynı servete sahip olana kadar servetlerinin vergilendirilmesiyle vergi sistemde adalet sorununun çözüleceğini öne sürmektedir. Mill ise devletin gelir dağılımını daha adil bir konuma getirmek için servetin vergilendirmesi gerektiğini öne sürmüştür. Genel olarak üzerinde çokça durulan bir kavram olan adalet, gelir dağılımının mükellef arasında eşit dağılması olarak özetlenebilmektedir.

Vergilemede adaletin sağlanmasında etkili olan faktörlerden bazıları vergi bilinci, vergi ahlakı, vergi idaresinin yapısı, denetim süreçlerinin etkinliği olarak sıralanabilmektedir (Akbey, 2014: 65).Türkiye'de Akbey (2014)'in 1995-2012 yıllarını ele alarak yaptığı çalışmasında, bu yıllarda uygulanan vergi politikasının dolaylı vergiler üzerine yüklendiğini ve bu durumun vergilemede adaleti daha da sürdürülemez bir konuma getirdiği sonucuna ulaşmıştır. Vergi mükelleflerinin vergi karşında tutum ve davranışlarının belirlenmesinde en önemli etkenlerden birinin adalet olması sebebiyle bu kavram vergi uyumunu, dolayısıyla mükelleflerin vergiye karşı göstermiş oldukları tepkileri etkileyebilmektedir (Çetin, 2007: 178).

\subsection{Vergi Yükü}

Vergi yükü, gelirin belirli bir vergi ya da harcama politikası arasındaki dağılımını inceler (Devarajan \& Hossain, 1998: 964). Kamu ekonomisinde tartışılagelen önemli sorulardan biri olan vergi yükü, vergi politikalarının ekonomik refah dağılımı üzerindeki etkisi olarak da tanımlanmaktadır (Kotlikoff \& Summers, 1987: 1043). Genel olarak toplum, özel olarak da mükellef çerçevesinden bakılırsa ödenen vergiler toplum ve bireyler açısından bir yük teşkil eder. Bu yük maddi nitelikte olur ise objektif vergi yükü, psikolojik nitelikte ise sübjektif vergi yükü olarak sınıflandırılmaktadır (Şen \& Sağbaş, 2015: 289).

Vergi teorisinin ana prensiplerinden biri de vergi yükünün mükellefler arasında nasıl dağılacağına yöneliktir. Bu dağılım, mükellef tarafından vergi yükünün bölüşümünde fedakârlık kavramı ve faydalanma ilkesi ile yakından ilişkilidir. Carver (1895) vergiyi bir "şeytan" olarak tanımlamış ve bu şeytanın, vergi ödeyenlerin ödemeyenlere göre bir fedakârlık göstermesi ve vergilerin şirketlerde sert etki yaratması olarak iki çeşide ayırmıştır. Bu etkinin hafifliğini de fayda prensibine ve vergi yükünün eşit dağılmasına bağlamıştır. Hükümet, vergilemede kişi ve sınıf ayrımı yapmamalı, vergi yükünü adil dağıtmak amacıyla bireylerin birbirlerine yakın seviyede vergi fedakârlığı göstermelerini sağlamalıdır. Eğer bir birey taşıması gerektiğinden daha az bir vergi yükü taşıyorsa, başka bir kişi daha fazla vergi yükü taşımak durumdadır. Diğer kişinin artan vergi yükü de bir "şeytan"dır (Carver, 1895: 95-96).

1988'lerde tartışılan vergi reform önerileri, vergi yükünün bireylerden kurumlara geçmesini savunmaktadır ve bu durum politik sorumluluk kavramını ihlal etmektedir. Bu düşünceyi savunanlar bireylerin vergi yükünü taşımaları gerçeğini unutmaktadırlar (Stiglitz, 1988: 18). 
Mükellefler, vergi yükünü ödenen vergi ile doğru, vergi ödeme gücü ile ters orantılı olarak hissetmektedirler (Aktan \& Çoban, 2006:140-141). Bu nedenle vergi yükünün oranı, vergi yükünün adil dağılmadığını düşünen mükelleflerin vergilemeye ilişkin tutum ve davranışlarını olumsuz yönde etkileyebilmektedir. Vergi yükünün mükellef tarafından hissedilme derecesi ile vergiye karşı tutum ve davranışları arasındaki ilişkiye yönelik yapılan çalışmalar, algılanan vergi yükü ile gelecekte vergi kaçırma düşüncesi arasında anlamlı bir ilişki olduğunu ortaya koymaktadır (Şahpaz \& Saruç, 2012). Özetle vergi yükü, adalet ve eşitlik kavramı ile ilişki içerisinde olan ve mükelleflerin vergiye karşı tepkilerini etkileyen bir kavramdır.

\subsection{Yolsuzluk Algısı}

Yolsuzluk genel itibariyle kamu gücünün özel çıkarlar için kullanılması şeklinde tanımlanmaktadır. Buradaki özel çıkar kavramı, parasal olabileceği gibi güç ve statü elde etme veya geleceğe yönelik üstünlük beklentisi anlamına gelmektedir (Lambsdorff, 2006: 16). Yolsuzluk kavramı kamu ekonomisi, kamu yönetimi, kamu hukuku gibi çeşitli alanlarında sıklıkla kullanılmaktadır (Tanzi \& Davoodi, 2000: 3).

Tanzi (1998), yolsuzluğun ortaya çıkmasını vergi sisteminde ortaya çıkan bazı sorunlara dayandırmaktadır:

- Vergi kanunlarının anlaşılmasının zor olması,

- Vergi alacaklısını ve borçlusunu sıklıkla yüz yüze getirmesi,

- Vergi toplayıcılarının gelirinin düşük olması,

- Mali saydamlığın eksikliği,

Yolsuzluk algısı ise, toplumun mali kuralları algılayışına, ananelerine, örf ve adetlerine bağlı olduğundan kültürel bir sosyal olgudur. Toplumsal faktörlerle birlikte, kişisel değer yargıları ve ahlak yapısı da yolsuzlukla ilişkilidir. Bir kişi rüşvet vermeyi ahlaki açıdan uygun bulmasa da başka bir kişi bu konuda ahlaki açıdan bir sakınca görmeyebilir. Bu durumda yolsuzluk algısı kişisel bakış açısıyla da ilgilidir. Sosyal ve kültürel faktörlerle sıkı ilişki içinde olan yolsuzluk, yüksek seviyede yapıldığında ülke ekonomisini olumsuz yönde etkileyebilmektedir (Melgar vd., 2010: 120). You \& Khagram (2005) yaptıkları çalışmada, bireylerin gelir dağılımı ile yolsuzluk arasında bir ilişkinin varlığına yönelik bulgular elde etmiştir.

Mali yolsuzluk gibi kötü yönetim uygulamaları mükelleflerin vergiye uyumlarını etkilemektedir. Bu tür uygulamalar, mükelleflerin yönetime ilişkin olumsuz düşüncelere sahip olmasına neden olarak mükelleflerin vergiye uyumlarını azaltabilmektedir (Tunçer, 2002: 119). Özetle, kamu gücünün özel/kişisel çıkarlar adına kullanılması anlamına gelen yolsuzluk, mükellef tutum ve davranışları üzerinde etkiye sahiptir. 


\subsection{Kamu Hizmetlerinden Memnuniyet}

Kamu harcamaları ile ödenen vergiler arasındaki ilişki literatürde mali bağlantı (fiscal connection) olarak nitelendirilmektedir. Vergilemede fayda prensibi, toplumda vergi bilinci ve vergi ahlâkı oluşumu açısından son derece önemlidir. Ödediği vergilerin kendisine kamu hizmeti olarak geri döndügünü düşünen mükelleflerin vergi kaçırma eğilimleri ve kayıt dışı faaliyetlere girişme eğilimlerinin azalması beklenmektedir (Demir \& Küçükilhan, 2013).

Yükümlülerin devlete yükledikleri görev veya yaratmış olduğu devlet imajı beklentisinin sonucu, devletin giriştiği faaliyetleri değerlendirerek, devlete vergi vermenin gerekli veya gereksiz olduğu inancına kapılabilir. Eğer devletin kötü yönetildiği, alınan vergilerin israf edildiği, verimli olarak değerlendirilip harcanmadığı şeklinde bir kanaat oluşursa, yükümlü vergi vermekten kaçınacaktır (Çataloluk, 2008: 219).

Hanousek \& Palda (2004) Çek Cumhuriyeti, Slovakya, Macaristan ve Polonya'da yaptığı çalışmada, bireylerin kaliteli kamu hizmeti almadığına inanmasının vergi kaçırmayı etkilediği üzerine güçlü bulgular elde etmiştir.

\subsection{Eğitim Seviyesi}

Eğitim, temel bir tanımla; "bireyin yaşadığı toplumda yeteneğini, tutumlarını ve olumlu değerdeki diğer davranış biçimlerini geliştirdiği süreçler toplamı" olarak açıklanabilir (Tezcan, 1985: 4). Tanımda görüldüğü üzere eğitimin üzerinde durduğu temel iki kavram yaşanan toplum içerisindeki tutum ve olumlu davranış biçimleridir. Dolayısıyla birey eğitim sayesinde edindiği tutumlar yoluyla aldığı kararları davranış biçimine dönüştürürken doğruluk kavramına göre hareket edecektir.

Eğitim, vergiye uyum davranışına etki eden temel demografik faktörlerden birisidir. Mali sosyoloji literatüründe, eğitim ve vergiye uyum arasındaki ilişkinin pozitif mi negatif mi olduğuna dair ortak bir kanı bulunmamaktadır. Bir kısım araştırmacılar, eğitim düzeyi yükseldikçe vergiye uyumun da artacağını savunurken, buna karşın bazı araştırmacılar da eğitimin artması sayesinde vergiden kaçınma ve vergi kaçırma olaylarının artması dolayısıyla vergiye uyumsuzluğun ortaya çıkacağını savunmaktadır.

Vergiye uyum ile eğitim arasındaki ilişkiyi pozitif yönüyle ele alan uluslararası çalışmalarda üzerinde durulan genel kanı eğitimin vergi hakkında bilgi sahibi olmayı sağladığı yönündedir. Öyle ki bir ülkede uygulanan vergi politikalarını anlamak ve desteklemek açısından yüksek eğitimli vatandaşlar daha öndedir (Shömelders, 1960; Aktaran Kirchler vd.,2007: 216). Bunun yanı sıra daha az eğitimli bireylerin vergi düzenlemeleri hakkında daha az bilgiye sahip oldukları, vergi konularında yardıma ihtiyaç duydukları ve bu nedenle de vergiye uyumlarının daha az olduğu düşünülmektedir (Vogel, 1974).

Bireylerin eğitim düzeylerinin yükselmesi, ödeyecekleri vergilerin sağlayacağı fayda ve hizmetlerin farkındalığını arttıracak ve bu durum onların vergiye uyumunu 
kolaylaştıracaktır (Torgler \& Murphy, 2004:313). Özetle; eğitim düzeyinin düşük olması, vatandaşlık bilincinin yerleşmemesi sebebiyle bireyler için vergiye karşı olumsuz bir tepki oluşmasına sebep olabilir. Bunun yanı sıra eğitim düzeyi vasıtasıyla mali konulardaki teknik bilgiye sahip olmak vergiye karşı olumlu bir tutum sergilemeye katkı sağlayacaktır (Carley \& Maxwell, 2006: 8; Çataloluk, 2006: 218).

Uluslararası literatürdeki genel kanının yanı sıra eğitim ile vergiye uyum arasındaki ilişkiyi daha farklı yorumlayan iktisatçılar da olmuştur. Örneğin Hite (1997)'ye göre bireylerin eğitim seviyeleri yükseldikçe vergiye karşı uyumları azalacaktır. Öyle ki eğitim düzeyi artan bireyler vergi kaçırmanın yollarını daha iyi bilecek ve bu sayede vergiye karşı olumsuz tutum edineceklerdir (Hite, 1997, Torgler \& Murhpy, 2004: 313). Benzer bir şekilde eğitimli bireylerin vergi kaçırma konusunda rasyonel davrandıkları da düşünülmektedir. Yani, birey vergi kaçırma sonucunda yakalandığında karşılaşacağı cezaları bildiği için vergi kaçırmak yerine vergiden kaçınmayı tercih edebilecektir. Bu nedenledir ki eğitim seviyesi artan ülkelerde vergi uyumunun azaldığı söylenebilir (Richardson, 2006: 152-161).

Mükelleflerin eğitim seviyesi yükseldikçe vergi karşısında daha duyarlı ve sorumlu davrandıkları (Muter vd., 1993: 63), eğitim düzeyinin düşmesiyle birlikte bazı mükelleflerin vergiye karşı olumsuz davranış geliştirdikleri ulusal literatürde de yaygın bir görüştür. Bunun yanında, kamu yöneticilerinin vergi bilincini artırmak amaçlı aile içi eğitime ve okul eğitimine önem vermesinin toplumun vergi bilincini yükseltmek yoluyla vergi uyumuna olumlu etki yapacağının da altı çizilmiştir (Ömürbek \& Çiçek, 2007: 117118). Türkiye'de yapılan bir çalışmada da vergi mükelleflerinin eğitim seviyelerinin yükselmesiyle birlikte vergilerin hangi alanlarda kullanıldığını merak etmeleri durumu, yani mali bağlantı bilgisi ortaya çıkmaktadır. Bu bulgudan hareketle, eğitimi yüksek vergi mükelleflerinin hükümetin harcama politikalarıyla yakından ilgilendikleri söylenebilir (Serim, 2015: 151).

Görüldüğü üzere literatür genelinde, eğitimin vergi uyumu üzerinde olumlu etki yaratacağı görüşü ağırlıktadır. Bunun yanı sıra bazı araştırmacılar eğitimin vergi konunlarındaki boşlukların bilinmesi yoluyla vergi kaçırma ya da vergiden kaçınmaya sebep olacağını ve böylelikle vergi uyumsuzluğu yaratacağını savunmaktadır.

\subsection{Gelir Seviyesi}

Verginin ortaya çıktığı tarihlerde tartışmalar vergi ne için alınmalıdır ve vergi neye göre alınmalıdır şeklindeki iki temel soru etrafında gelişmiştir. Bunlardan "vergi neye göre alınmalıdır" sorusuna cevap ise "fayda yaklaşımı" ve "ödeme gücü yaklaşımı" olarak iki farklı şekilde olmuştur (Şen \& Sağbaş, 2012: 10). Kişinin kendisinin ve ailesinin yaşamını asgari şartta sürdürmeye yetecek gelirden fazlası, o kişinin vergi ödeme gücü olarak tanımlanmaktadır.

Bireyler gelirlerinden azalmaya sebep olduğunda vergilere karşı tepki gösterebilirler. Gelir grupları açısından değerlendirildiğinde bu tepkiler, düşük gelir 
gruplarında zorunlu tüketimden kısılarak telafi edilmeye çalışılırken, yüksek gelirlilerde ise tasarruflar kısılarak refah eski seviyeye getirilmeye çalışılır. Bireylerin gösterdiği tepkiler hissettikleri vergi yüküne göre (sübjektif vergi yükü) değişecektir. Buradan hareketle düşük gelirlilerin vereceği tepkiler daha sert bir yapı sergileyebilir. Bu tepkilerin azaltılması için asgari geçim indirimi, ayırma ilkesi, negatif gelir vergisi gibi çeşitli bazı uygulamalar bulunmaktadır (Çataloluk, 2006: 216).

Bazı çalışmalarda gelir seviyesi ve vergi uyumu arasında bir ilişki bulunmadığı savunulsa da (Friedland vd., 1978) gelir düzeyinin vergiye uyum üzerinde olumlu ya da olumsuz bir etkisi olduğu literatür genelinde kabul gören bir durum hâlini almıştır (Ömürbek \& Çiçek, 2007:110). Fakat araştırmacılar bu etkinin ne yönden olduğu konusunda farklı görüşlere sahiplerdir. Witte \& Woodbury (1985) tarafından yapılan bir araştırmada orta gelir gruplarının üst ve alt gelir gruplarına göre vergiye daha rahat uyum sağladıkları sonucu ortaya konmuştur. Yapılan başka bir çalışmada ise bireylerin gelir durumu ile eğitim durumu arasında bir bağlantı kurulmuş ve düşük gelir gurubundaki mükelleflerin, orta ve yüksek gruptaki mükelleflere oranla daha bilgisiz oldukları, bu nedenle vergiye uyumsuzluk gösterecekleri sonucuna varılmıştır (Ritsema, 2001:11). Konuya daha genel perspektiften bakıldığında ise, vergi oranlarının arttığı bir ortamda gelir grupları içerisinde sadece yüksek gelirlilerin vergi kaçırma eğilimine girebilecekleri düşünülmektedir (Andreoni vd., 1998).

Vergiye uyum ile gelir seviyesi arasındaki ilişkinin ödeme gücü paydasında geliştiği düşünülürse, bireyin vergi ödeme gücü ile ilişkisi açısından ülkedeki milli gelir ve bunun adil dağılımı da vergiye uyum için hayati önem taşımaktadır. Zira bir ülkenin milli gelirinin yüksek olması ve milli gelirin vatandaşlara adil bir şekilde dağıtılması sonucu bireylerin vergi ödeme gücü yükselecektir ve bu da vergi uyumuna etki edebilecek bir sonuç ortaya çıkaracaktır (Yaraşı, 2005: 114). Milli gelirin vatandaşlara adil bir şekilde dağıtılması devletin adil ve etkin bir vergi sistemi kurmasıyla ilişkili bir durum olduğundan, eğer devlet bunu başaramazsa yükümlülerin de vergi karşısındaki tutumlarının olumlu olması beklenemeyecektir (Muter vd., 1993: 25).

Gelir seviyesinin düşük olması vergi kaçırma arasındaki ilişkiyi açıklamak açısından vergi kaçırmanın marjinal faydası kullanılabilir. Bu ilişki üzerindeki genel kanı, gelir seviyesi düşük olan bireylerin vergi kaçırma eğilimlerinin düşük olduğunu çünkü bu kişiler için vergi kaçırmanın marjinal faydasının çok az olduğunu belirtmektedir (Taytak, 2016: 1942). Yüksek gelir grupları alt gelir gruplarına nazaran kamu harcamalarına daha fazla katıldıkları hissine kapılarak kamu hizmetlerinin daha kapsamlı ve kaliteli olmasını bekleyebilirler. Bu beklentinin gerçekleşmemesi ise vergiye olan uyumlarını azaltabilir. Ayrıca buna ek olarak gelir yükseldikçe vergi ödevleri daha da artar ve karmaşıklaşır, bu yoğunluk ise vergi uyumsuzluğuna sebep olabilir (Yeniçeri, 2001: 282). Diğer taraftan yüksek gelir gruplarının daha fazla tasarruf sahibi oldukları göz önüne alındığında, devletin tasarruflar üzerinden talep ettiği vergiyi etkin ve doğru bir şekilde toplumsal kullanıma konu etmesi gerekir. Aksi halde zaten özü gereği gönüllü olarak vergi ödemek istemeyen mükelleflerin vergiye karşı tutumu daha da olumsuz hale gelecektir (Duran, 2001: 73). 


\subsection{Rasyonel Gerekçelendirme}

Mükelleflerin vergiye uyumunu etkileyen faktörler arasında gerekçelendirme kavramı için vergi literatüründe herhangi bir tanım bulunmamaktadır. Büyük Türkçe Sözlüğünde gerekçe kavramı genel bir tanımla "Gerektirici sebep ya da bir önermenin kendiliğinden var kıldığı gereklilik" olarak tanımlanırken hukuki anlamda ise "Bir yasanın önerilmesi ve hazırlanmasında, yasa tasarısının hazırlanış ve maddelerin düzenleniş sebepleri veya Mahkeme kararlarında, kararın dayandığı yasal ve hukuksal sebeplerin gösterilmesi" olarak açıklanmaktadır (TDK, 2017). Hukuk literatüründe kabul gören tanıma göre ise gerekçe; "Bir yasa tasarısının maddelerinin hazırlanış ve düzenleniş sebepleri, mahkeme kararlarında kararın dayandığı yasal ve hukuki sebebin gösterilmesi, yargıcın hükmünün dayandığı nedenler ve son olarak bir kanunun neden çıkarılmış olduğunu gösteren açıklama" olarak tanımlanmıştır (Yılmaz, 1992: 307).

Hukuksal anlamda yapılan tanımları vergilendirme kanunları açısından değerlendirirsek gerekçelendirme kavramı, vergi kanunlarında yapılan değişikliğin vergi oranı artışı veya yeni vergi konulması gibi- vergilendirme yetkisi bulunanlarca yapılan bir açıklamayla konjonktürel bir konuya veya duruma bağlanması olarak açıklanabilir. Türkiye'de yaşanan 17 Ağustos 1999 ve 12 Kasım 1999 depremlerinin yaralarının sarılması amacıyla bir defaya mahsus olarak alınacağı açıklanan Özel İletişim Vergisi ve bunun yanı sıra zaten alınmakta olan kişisel-kurumlar Gelir Vergisi, Emlak Vergisi ve Motorlu Taşıtlar Vergisine de ek vergi getirilmesi bu duruma iyi bir örnek teşkil etmektedir. Yaşanan doğal afet sonrası getirilen bu vergisel yükümlülüklerin gerekçesi olarak ise direkt olarak kanunun isminde "depremin açtığı ekonomik kayıpları gidermek" ibaresine yer verilmiştir .

\subsection{Enflasyon}

Enflasyon, genel anlamda, fiyatlar genel seviyesinde meydana gelen sürekli artışlar olarak tanımlanabilir. Uluslararası literatürde vergi uyumu ve enflasyon arasındaki ilişkiyi açıklamaya yönelik çeşitli yaklaşımlar olmuştur. Bu ilişkinin negatif olduğuna dair ortak zeminde toplanabilen bu yaklaşımlar hem enflasyonun ekonomik etkilerine hem de psikolojik etkilerine değinmişlerdir. Ekonomide oluşan enflasyon, bireylerin gelirlerinin nominal değerini artırmak suretiyle bir üst vergi dilimine dahil olmalarına sebep olacaktır. Satın alma gücü yükselmeyen birey buna karşın daha fazla vergi ödemek durumunda kalırsa sonuçta vergiye karşı bir uyumsuzluk ortaya çıkacaktır (Graetz \& Wilde, 1985).

Enflasyonun vergi uyumu üzerinde yarattığı etkiler ekonomik tabanlı olabileceği gibi psikolojik durumlara da dayanabilir. Enflasyon bireylerin mevcut gelirini düşürür ya da düşeceği kaygısını yaratır. Bu nedenden ötürü enflasyonist ortamda ya da enflasyon beklentileri varken bireylerin vergiye uyumu düşük olacaktır. Bu durum da enflasyon ile vergi uyumu arasında negatif bir korelasyon olduğunun bir göstergesidir (Fishlow \& Friedman, 1993). 
Enflasyon ve vergi uyumu ilişkisi ulusal alanda da farklı yaklaşımlarla açıklanmaya çalışıımıştır. Genel olarak uluslararası literatüre paralel bir durum söz konusuyken yaklaşımlar para aldanımı, mali sürüklenme gibi ekonomik faktörler ile psikolojik faktörler şeklinde karşımıza çıkmaktadır.

Enflasyonist dönemlerde artan oranlı tarife uygulanan ülkelerde alt dilimde yer alan düşük gelir grupları ekonomik genişleme sebebiyle üst dilimlere kayacak ve bu da vergi yükünde bir adaletsizlik ortaya çıkaracaktır. Bir başka deyişle, enflasyonist dönemlerde mükelleflerin gelirleri reel olarak artmamakla beraber vergi diliminde bir üst dilimde yer alacaklardır. Bu durum mali sürüklenme olarak adlandırılmaktadır. Bu adaletsizlik neticesinde de mükelleflerin vergiye uyumunda bir azalma oluşabilir. Bu durum da enflasyonun vergiye uyumu dolaylı yoldan etkilediğinin bir göstergesi kabul edilebilir (Çataloluk, 2006; Saygın, 2013:133).

Başka bir yaklaşıma göre mükellefler ekonomik kriz dönemlerinde, diğer dönemlere oranla, daha olumsuz tepki göstermektedir. Öyle ki bu dönemlerde bireyler ekonomik iflasa daha yakın oldukları hissine kapılır ve bu neden vergi kaçırma eğilimine gidebilirler (Benk \& Çetin, 2010: 105).

\subsection{Hükümete Güven Düzeyi}

Güven; taahhütlerini yerine getirme, içtenlik, gerçeklik, dürüstlük ve erdemi kapsamaktadır. Toplumsal düzenin, bireysel yaşamın, ekonomik ve demokratik gelişmenin temelini güven duygusu oluşturmaktadır (Gökalp, 2003: 163).

Birey-devlet ilişkilerinin sağlıklı ve gönüllü uyumun yüksek olabilmesi için bireylerin devlete ait kurum ve kuruluşlarına güven duyması gerekmektedir (Gencel \& Kuru, 2012: 34). Bireylerin devlete duydukları güven duygusu vergi ödeme isteklerini artırmaktadır (Cansız, 2006; Çataloluk, 2008: 219).

Devlete ve kurumlara duyulan güven duygusunun mükelleflerin psikolojisini olumlu etkilediğine yönelik bulgular tespit edilen çalışmalar mevcuttur (Abdieva \& Cumakunova, 2016; Cansız, 2006; Gürler \& Hazman, 2009; Kaynar Bilgin, 2011; Çevik, 2012; İzgi Şahpaz \& Saruç, 2012; Torgler, 2003b; Torgler, 2004; Torgler \& Murphy, 2004; Martinez-Vazquez \& Torgler, 2009; Torgler \& Schneider, 2006, Turan \& Yurdakul, 2014, Yeniçeri \& Çevik, 2014).

\subsection{Savurganlık}

Vergi ödemede mükelleflerin motivasyonlarından biri de ödedikleri vergilerin harcandıkları yerler ve harcama biçimleridir. Mükellefin toplanan vergilerin gerektiği yerlere gerektiği şekilde harcanmadığına yönelik algılaması vergiye karşı bakış açısını değiştirebilmekte, vergiye tepki göstermesine neden olabilmektedir. Mükellefler ödedikleri vergileri kamu harcamalarının karşılığı olarak algılamakta ve bu nedenle yapılan kamu harcamalarına duyarlılık göstermektedir. Kamusal harcamaların 
toplumun beklentilerini karşılamaması ve yönetimin savurgan olması gibi kötü yönetim uygulamaları mükelleflerin adalet düşüncelerini zedeleyerek vergiye uyumlarını olumsuz yönde etkilemektedir. Mükellefler idare tarafından gereksiz ve lüks harcamaların yapılması, ödedikleri vergilerin toplum yararı yerine geniş halk kitlelerince benimsenmeyen kesimlere aktarılmasını adaletsiz olarak görebilmekte ve devlete olan güvenlerini sarsarak rahatsız edebilmektedir. Bu durum, mükelleflerin vergi ödeme motivasyonlarının sübjektif niteliğine işaret etmektedir. Mükelleflerin devlet ve toplumla olan ilişkileri vatandaşların vergi ödeme konusundaki içsel motivasyonlarını, dolayısıyla vergiye uyumlarını etkilemektedir (DPT, 2001:14; Savaşan \& Odabaş, 2005: 6; Şahpaz \& Saruç, 2012: 67; Tosuner \& Demir, 2007: 15; Tunçer, 2002: 119).

Bayraklı vd. (2004), Çiçek vd. (2008), Şahpaz \& Saruç, 2012; Yüce, 2004; Zenginobuz vd. (2010) tarafından yapılan çalışmalarda, araştırmaya katılan bireylerin çoğunluğunun kamu harcamalarında savurganlık yapıldığını düşündükleri görülmektedir.

\subsection{Vergi Affı}

Vergi affı, devletin egemenlik yetkisine dayanarak bireylerden alınan vergi, resim ve harçların tahsilinden ve vergilendirme ödevinin yerine getirilmemesinden doğan yaptırımların uygulanmasından devlet tarafından vazgeçilmesidir (Edizdoğan \& Gümüş, 2013: 99-100). Buna göre, vergi affı uygulaması ile devlet vergi ve benzeri alacaklarından bilinçli olarak vazgeçmektedir. Türkiye'de mali af kapsamında ilk vergi affı uygulaması 17 Mayıs 1924 yılında yapılmış ve günümüze kadar farklı şekillerde de olsa sıklıkla uygulanmıştır (Çetin, 2007: 177).

Vergi afları; bireylere ödenmemiş vergilerini ödeme imkânı vererek kısa vadede devlete gelir sağlamaktadır. Af yanlılarının vergi affını savunmalarının en büyük dayanağı da bu gelir etkisidir (Yaraşır, 2013: 177). Ancak devletin gelirlerinde azalma şeklinde maddi kayıp ile vergi bilincinin ve ahlakının yitirilmesi şeklinde manevi kayıplara yol açması sebebiyle vergi affının karşıt görüşü bulunmaktadır. Hükümetlerin vergi affı uygulamasına sıkça başvurmaları mükelleflerin af beklentisi sebebiyle ödemeleri gereken vergileri ödemeyi ertelemelerine ya da hiç ödememelerine sebep olmaktadır. Bu durum, bireylerin vergi bilinci ve ahlaklarını da etkilemekte ve devletin vergi gelirlerinin erimesinden ötürü vergi erozyonu ortaya çıkmaktadır (Öz \& Buyrukoğlu:2011, 93). Ayrıca sıklıkla uygulanan vergi aflarının, vergi ödevlerini zamanında yerine getiren dürüst addedilebilecek mükellefler üzerinde olumsuz psikolojik etki ile eşitsiz ve adaletsiz bir durum ortaya çıkarması da vergi aflarının manevi kayıplarından biri olarak ele alınabilir (Şenyüz, 2014: 96).

Yapılan ampirik çalışmaların bulguları da bu savları destekler niteliktedir (Cansız, 2006; Çetin, 2007; Çiçek vd., 2008; Tuay \& Güvenç, 2007; Yeniçeri, 2005). Muter vd. (1993) tarafından mükelleflerin vergi karşısındaki tutum ve davranışlarının araştırıldığı çalışmada vergi kaçırma davranışını hoş görmeyen ve tepki gösteren mükelleflerin, 
vergi affı uygulamasına karşı tutumlarının olumsuz olduğu tespit edilmiştir. Bu tespit, vergi kaçırma davranışına olumlu bakan bireylerin vergi aflarını olumlu karşıladıklarını, yani bireylerin kişisel çıkarlarına göre tutum ve davranış geliştirdiklerini göstermesi bakımından dikkat çekici olmuştur.

\subsection{Yurtseverlik}

Yurtseverlik kavramı, TDK tarafından "yurdunu, milletini büyük bir tutku ile seven, bu uğurda her türlü özveriye katlanan (kimse), vatansever, vatanperver" olarak tanımlanmaktadır. Bu tanım, bireyin; vatanına olan sevgisini, bağlılığını ve vatanı için fedakârlık yapmaya hazır vaziyetini kapsamaktadır. Tanımından da anlaşılacağı üzere yurtseverlik kavramı oldukça kapsamlıdır.

Ersoy \& Öztürk (2015) tarafından sosyal bilgiler öğretmen adaylarının yurtseverliğe ilişkin algılamalarının araştırıldığı çalışmada, öğretmen adaylarının yurtseverliği; ülkeyi sevmek ve bağlı olmak, görevleri ve sorumluluklarını yerine getirmek ile demokrasi ve insan haklarının gelişmesi için çaba harcamak biçiminde algıladıkları tespit edilmiştir. Yurtseverlik duygusu, vatandaşların siyasi ödevi olarak hükmolunan vergi ödevinin yerine getirilmesini de içermektedir. Alm (2010) bireylerin ekonomik davranışlarının motivasyon kaynağının, standart neoklasik yaklaşımın aksine yalnızca kişisel çıkar güdüsü olmadığını; itaat, fedakârlık, karşılıklılık, güven, suçluluk, utanç, ahlak, yabancılaşma, sosyal gelenekler, sosyal normlar ve yurtseverlik duygusu gibi başkaca faktörlerin de bireylerin motivasyonunda etkili olabildiğini savunmaktadır. Vergi verme davranışı, bireyin ekonomik bir davranışı olarak ele alındığında yurtseverlik duygusunun bireyin vergi verme davranışını motive eden bir faktör olduğu anlaşılmaktadır.

Yurtseverlik ve vergi uyumu ilişkisinin araştırıldığı çalışmada Konrad \& Qari (2009: 26) yurtseverliğin vergi uyumunun önemli bir belirleyicisi olduğu tespit etmiştir. Yurtseverlik duygusunun vergi tahsilatını kolaylaştırabileceği, daha az vergi denetimi olan ortamda dahi daha yüksek uyuma sebep olabileceği sonucuna ulaşılmıştır

Osmanlı maliye sisteminde önemli yer tutan ağnam vergisinin Milli Mücadele Dönemi'nde de tahsil edilmesine yönelik hükümet çalışmalarında yurtseverlik duygusunun vergi ödevi ile ilişkilendirildiği tespit edilmiştir. Maliye Vekâleti tarafından maliye memurlarına verilen talimatların birinde "içinde bulunulan durumun nezaketinin ve ordunun paraya olan ihtiyacının takdir edilerek, tahsilâtta ihtimam gösterilmesinin yurtseverlik gereği olduğu" ifadesi yer almaktadır (Aktaran Gönüllü, 2015: 76). İlgili talimattan, bireylerin vergi ödevini yurtseverlik duygusuyla yerine getirmelerinin yanı sıra maliye memurları tarafından vergi tahsilatının yapılmasında da gayretlerinin motivasyonu olarak yurtseverlik duygusuna işaret edildiği görülmektedir.

Genel olarak, yurtseverlik duygusunun bireyleri vergiye karşı olumlu tutum ve davranışlara yönlendirdiği görülmektedir. Ancak 1786-1787 yıllarında Amerika'nın İngilizlere karşı başlattığı bağımsızlık mücadelesini kazanmasından sonra ortaya çıkan 
ve "Shays İsyanı" olarak isimlendirilen vergi isyanına bakıldığında ise, vergi isyanının isim babası Shays'ın yurtsever kimliğine rağmen vergi isyanı girişiminde bulunduğu görülmektedir. Bu durum, yurtseverlik duygusunun bireyleri her zaman vergi uyumunu arttırmaya yönlendirmeyeceğini göstermektedir (Aktan vd., 13-14).

\subsection{Vergi Kanunlarının Değişme Hızı}

Vergi sistemimizde en çok karşılaşılan olaylardan biri vergi kanunlarının sık sık değişmesidir. Vergi mevzuatının sık sık değişikliğe uğraması, karmaşık yapıya bürünmesine ve mükellefin uyum gösterme gayretini de engelleyebilmektedir.

Cuccia \& Carnes (2001), yaptıkları araştırmada vergi ahlâkı ile vergi yapısının karmaşıklığı arasında anlamlı bir ilişki bulmakla beraber, vergi sisteminin karmaşıklığının vergi ahlâkını açıklamada tek başına yeterli olmayacağını öne sürmüşlerdir.

\subsection{Vergi İdaresi Algısı}

Mükellefin vergi karşısındaki davranışlarını etkileyen faktörler arasında vergi idaresinin etkinliği de yer almaktadır. Vergiyi doğuran olayın başlamasıyla birlikte vergilendirme sürecini kapsayan verginin tarhı, tahakkuku, tebliği ve tahsilatına kadar geçen aşamalarda idarenin etkin rolü ve görevi vardır. Vergi idaresi bu görevini vergi kanunlarını uygulama görev ve yetkisiyle yerine getirir.

\subsection{Verginin Konusu (Yerinde Kullanılıp Kullanılmadığı)}

Devletin tahsil ettiği vergi gelirleriyle finanse edilen harcamaların içerik, etkinlik, verimlilik ve ekonomik olup olmadığı gibi unsurlar o mal ve hizmetten yararlanan kadar, onun külfetini ödediği vergilerle üzerinde taşıyan mükellefi de ilgilendirmektedir (Alkan, 2009: 28).

\subsection{Fırsatçılık}

Fırsatçı (Oportünist) davranış kavramı, "kurnazca kendi çıkarlarını öne çıkarmak" şeklinde tanımlanabilir. Yine, oportünist davranışın özü, bir kişinin kendisine verilen rol ile ilgili olarak örtülü veya açık bir şekilde aldatmaya yönelik faaliyetlerinden ibarettir. İlişki içinde bulunan taraflardan biri, diğerinin oportünist davranışlarda bulunduğuna inanırsa, ilişki zarar görecektir. Bu tip algılamalar, taraflar arasında güvenin azalmasına yol açacaktır. Ayrıca, oportünist davranışlar ilişki bağlılığını azaltıcı yönde etkiler doğuracaktır. (Morgan \& Hunt, 1994: 25).

Literatürde açıklandığı üzere vergiye yönelik tutum ve davranışlar üzerinde adalet (Çetin, 2007), vergi yükü (Aktan \& Çoban, 2006), yolsuzluk algısı (Tunçer, 2002), mükelleflerin kamu hizmetlerinden memnun olup olmaması (Hanousek \& Palda, 2004; 
Çataloluk, 2008), vatandaşların eğitim düzeyi (Muter vd., 1993; Serim, 2015), gelir seviyesi (Yeniçeri, 2001; Taytak, 2016), enflasyon (Çataloluk, 2006; Saygın, 2013), mükelleflerin devlete ve kurumlara olan güveni (Cansız, 2006; Çataloluk, 2008; Gencel \& Kuru, 2012), savurganlık (Savaş ve Odabaş, 2005; Şahpaz \& Saruç, 2012), vergi affı (Şenyüz, 2014) faktörlerinin etkisi vardır.

\section{Metodoloji}

Çalışmada, Braun \& Clarke (2006) tarafından önerilen adımları takip ederek niteliksel analiz yöntemlerinden tematik analiz yöntemi kullanılmaktadır. Araştırma kapsamındaki veriler, Twitter sosyal medya platformundan toplanmıştır. Twitter'ın veri kaynağı olarak seçilmesinin nedeni, toplumun her kesimine ulaşma olanağının bulunması, verilerin web sayfasında (tweet) açık bir şekilde yer almasıdır.

Tematik analiz, en basit haliyle nitel bilgiyi kodlama yöntemidir. Bu yöntem çeşitli temaları listeleyerek, herhangi bir konu ile ilgili konuları, göstergeleri listeleyerek, bir biçim oluşturmayı amaçlar (Boyatzis, 1998).

Tablo 1: Tematik Analizin Aşamaları

\begin{tabular}{|l|l|}
\hline \multicolumn{1}{|c|}{ Aşamalar } & \multicolumn{1}{c|}{ Analiz Süreci } \\
\hline 1. Veriye aşinalık sağlama & Verileri tekrar tekrar okuma ve önemli detayları not alma \\
\hline 2. Ön kodlar oluşturma & $\begin{array}{l}\text { Verilerde ilginç bulunan noktaların sistematik bir şekilde } \\
\text { kodlanması, verileri kodlara ayırma }\end{array}$ \\
\hline 3. Temalar arama & Verilerin tümünü potansiyel temalara ayırma \\
\hline $\begin{array}{l}\text { 4. Temaları gözden geçirme } \\
\text { 5. Temaları isimlendirme ve } \\
\text { tanımlama }\end{array}$ & $\begin{array}{l}\text { Veriler kodlara doğru bir şekilde ayrılmış mı kontrol etme, } \\
\text { analizin tematik haritasını oluşturma }\end{array}$ \\
\hline $\begin{array}{l}\text { 6. Rapor oluşturma } \\
\text { Her bir temaya uygun isim verme ve bunları tanımlama }\end{array}$ \\
\hline
\end{tabular}

Kaynak: Braun \& Clarke (2006)'dan derlenmiştir.

Tablo 1'de tematik analizin altı aşaması ve analiz süreçlerine ilişkin bilgiler yer almaktadır. Aşamalardan ilki, veriyi okuyarak verilere aşinalık sağlama ile başlamaktadır. Analizin diğer aşamaları; kodların ve temaların oluşturulması, düzenlenmesi, isimlendirilmesi, tanımlanması ve ilgili literatür çerçevesinde yorumlanması şeklindedir.

\subsection{Araştırma Verileri}

Çalışmada, Motorlu Taşıtlar Vergisi ve Gelir Vergisi tarifesinin üçüncü dilimi oranlarına artış yapılacağı üzerine mükellefler tarafından verilen tepkiler incelenmek üzere, Twitter sosyal medya platformundan artışın gerçekleştiği ve gündemde kaldığı 
27 Eylül 2017-14 Ekim 2017 tarihleri arasında atılan tweetler aşağıdaki etiketler (hashtag) ile aranmıştır:

- Vergi Zammı

- Vergi

- Vergi Artışı

- Vergileme

- MTV

- Motorlu Taşıtlar Vergisi

- MTV Artışı

- Motorlu Taşıtlar Vergisi Artışı

- Gelir Vergisi

- Gelir Vergisi Artışı

- Gelir Vergisinin 3. Dilimi

Şekil 2: Araştırma Verileri

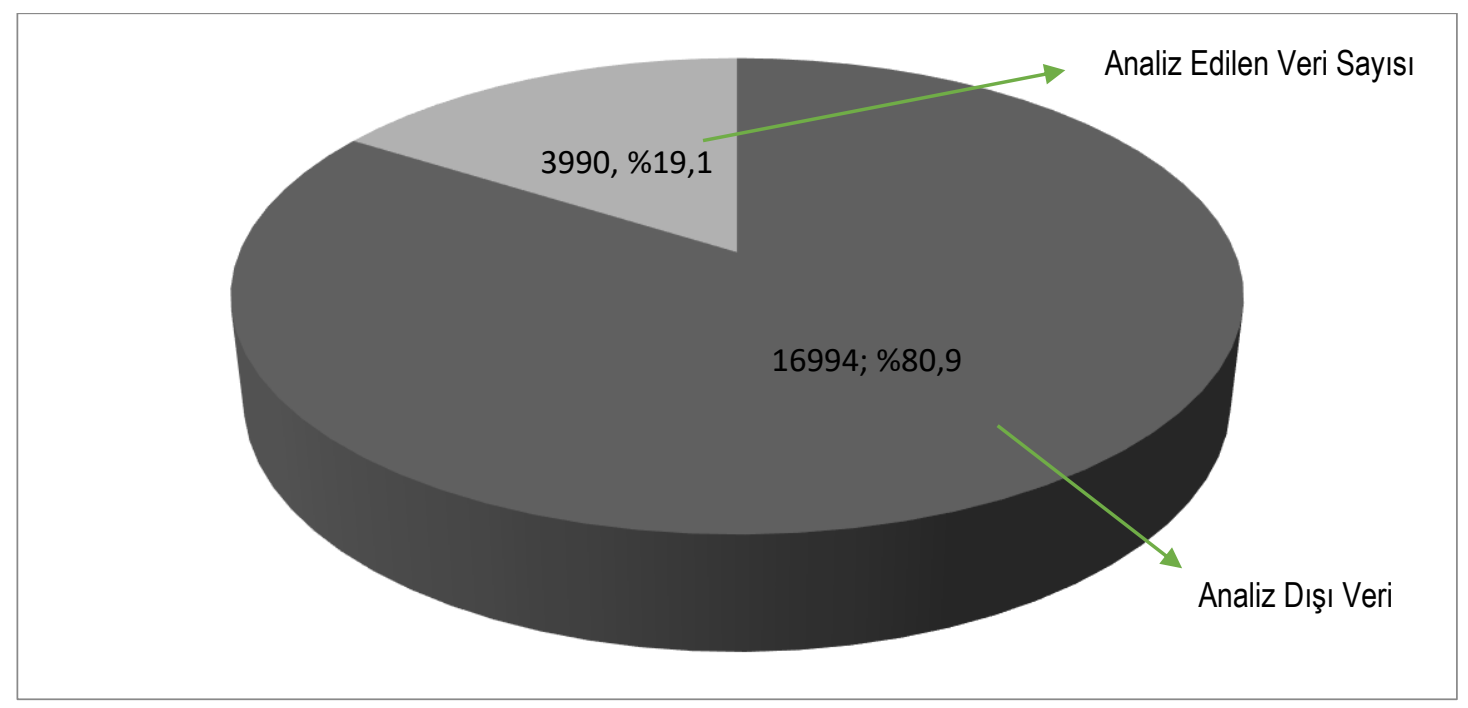

Şekil 2'de araştırmada incelenen veri (tweet) sayısı gösterilmektedir. 3.990 adet veri analize dâhil edilirken, 16.994 adet veri araştırma kapsamı dışında bulunmuştur. Araştırma kapsamı dışında olan verilerin büyük çoğunluğu ilgili vergilerin oranlarındaki artışın duyurulması niteliğinde olan ve muhtelif haber portalları tarafından otomatik üretilen tweetlerden (Örneğin MTV oranı \%25 oldu) oluşmaktadır. Kapsam dışı tutulan diğer bir grup tweetler ise araştırma ile ilgisi olmaması nedeni ile araştırma verisine dahil edilmemiştir. Bu verilerde tweetler sadece hakaret içermesi (kötü söz/küfür gibi), 
aynı kullanıcı tarafından mükerrer atılan tweetler ve sadece reklam içeriği olan tweetler gibi sebeplerle analiz dışında bırakılmıştır.

Çalışmada verilerin toplanması herhangi bir software kullanarak yapılmamış ve tek tek araştırmacılar tarafından toplanmıştır. Böylece datanın temizlenmesi ve geçerliliği ile ilgili kaygıların önüne geçilmeye çalışımıştır. Braun \& Clarke (2006)'ında belirttiği gibi niteliksel analizde çok önemli ve sağlanması niceliksel analize göre daha güç olan geçerlilik ve güvenilirlik kaygıları, araştırmacılar arasında datanın çapraz kontrolllerinin (datayı toplayan ve tweetlerin gerçekliğini kontrol eden) kişilerin farklı kişiler olması ve yapılan karşılıklı çapraz kontroller ile aşılmaya çalışılmıştır. Tweetlerdeki geçerliliğin yansıtılması açısından kullanıcı adı ve tarih belirtilmiştir. Bu şekilde tweetlerin gerçek kullanıcılara ait olup olmadığının kontrolünün yapılmasının yolu açılmıştır.

Tematik analiz yapılırken öncelikle ilk data kodları oluşturulmuş ve bu şekilde temların oluşması sağlanmıştır. Temaların oluşturulmasının ardından literatürde öngörülen faktörler etrafında mevcut temaların uyumu göz önünde bulundurularak kulanılabilir data kategorize edilmiştir. Tablo 2'de çalışmada analiz edilen veriler, verileri açıklayan temalar ve alt temalar yer almaktadır.

Tablo 2: Verileri Açıklayan Temalar İtibarıyla Analiz Edilen Verilerin Sayısı

\begin{tabular}{|c|c|c|c|}
\hline & Temalar & Alt Temalar & $\begin{array}{c}\text { Analiz Edilen } \\
\text { Verilerin Sayısı }\end{array}$ \\
\hline \multirow{2}{*}{1} & \multirow{2}{*}{ Vergilemede Adalet } & Olumsuz Tepki & 500 \\
\hline & & Olumlu Tepki & 3 \\
\hline 2 & Vergi Yükü & & 384 \\
\hline 3 & Savurganlık & & 128 \\
\hline \multirow{8}{*}{4} & \multirow{8}{*}{ Hükümete Güven } & Güven Zedelenmesi & 270 \\
\hline & & Mizahi Eleştiri & 378 \\
\hline & & Taktik-Oyun & 653 \\
\hline & & Yolsuzluk Algısı & 13 \\
\hline & & Halka Yönelik Eleştiri & 147 \\
\hline & & Gündem Değiştirme & 33 \\
\hline & & Medyayı eleştiri & 18 \\
\hline & & Olumlu Tepki & 62 \\
\hline 5 & Gelir & & 513 \\
\hline 6 & Vergi Affı & & 174 \\
\hline 7 & Enflasyon & & 77 \\
\hline 8 & Fırsatçılık & & 637 \\
\hline
\end{tabular}

Şekil 3'te araştırma kapsamında incelenen ve analize dâhil edilen verilerin değerlendirilmesi ile oluşturulan kavramsal çerçeve yer almaktadır. Literatür incelemesi sonucunda oluşturulan kavramsal çerçeve, verilerin değerlendirilmesi 
sonrasında ve analiz sonunda sadece datanın desteklediği faktörleri göz önünde bulundurarak revize edilmiştir. 50 tweet'ten az veri içeren vatan sevgisi, gerekçelendirme, eğitim, vergi kanunlarının değişim hızı, verginin konusu ve vergi idaresi algısı kavramları analiz dışında bırakılırken yolsuzluk algısı başlığı, hükümete güven başlığı kapsamına alınmıştır. Bu bağlamda, çalışmanın kavramsal çerçevesi Şekil 3'te yer alan kavramlar üzerine oturtulmuştur.

\section{Şekil 3: Kavramsal Çerçeve (Verilerin Değerlendirilmesiyle Oluşturulan Son Model)}

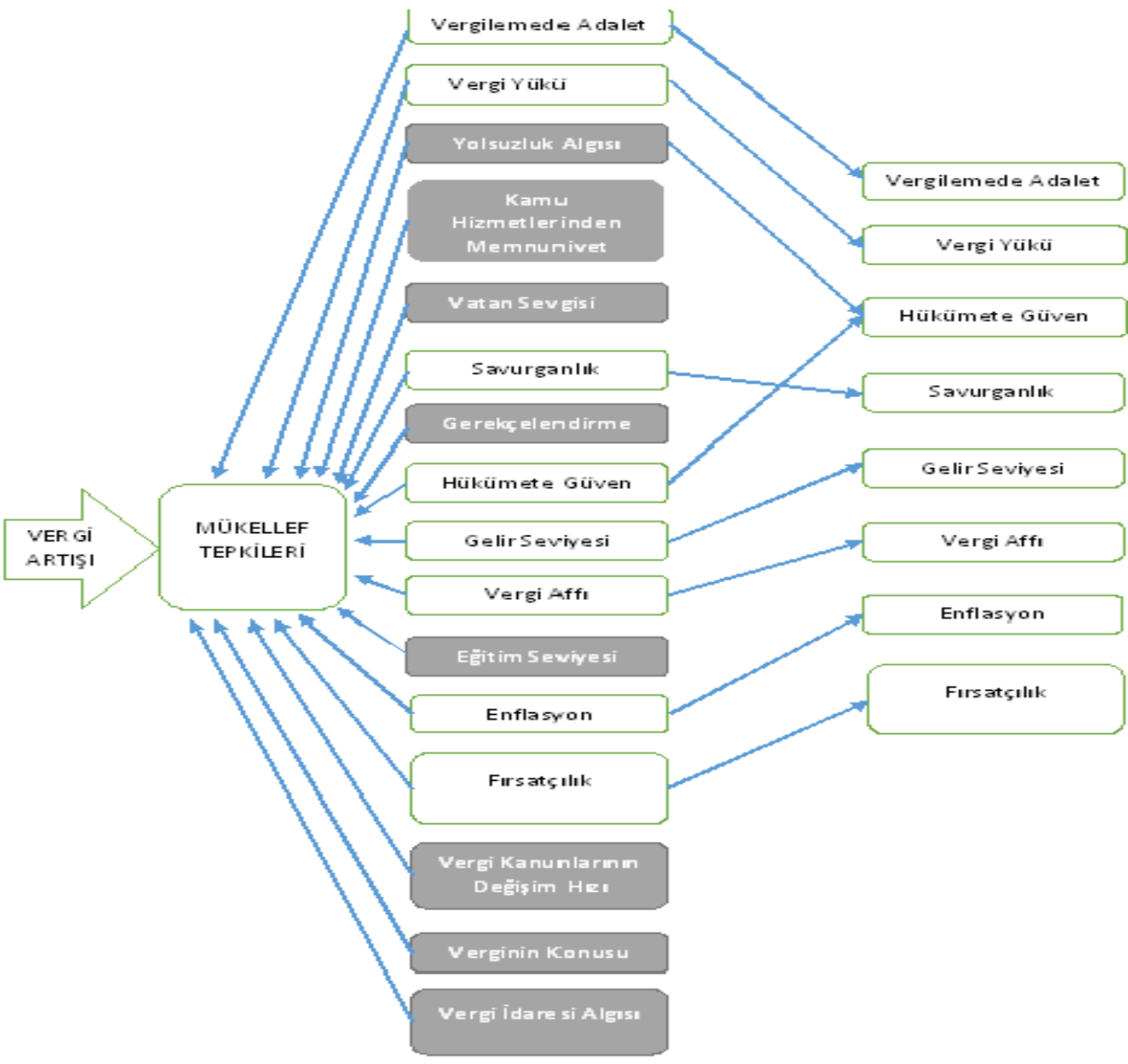

\subsection{Araştırma Bulguları}

Çalışmanın bu kısmında, mükelleflerin en fazla tepki gösterdiği veriler ve verileri açıklayan temalar tweet örnekleri üzerinden değerlendirilmektedir. 


\section{Grafik 1: Analiz Edilen Verilerin Verileri Açıklayan Temalar İçerisindeki Dağılımı}

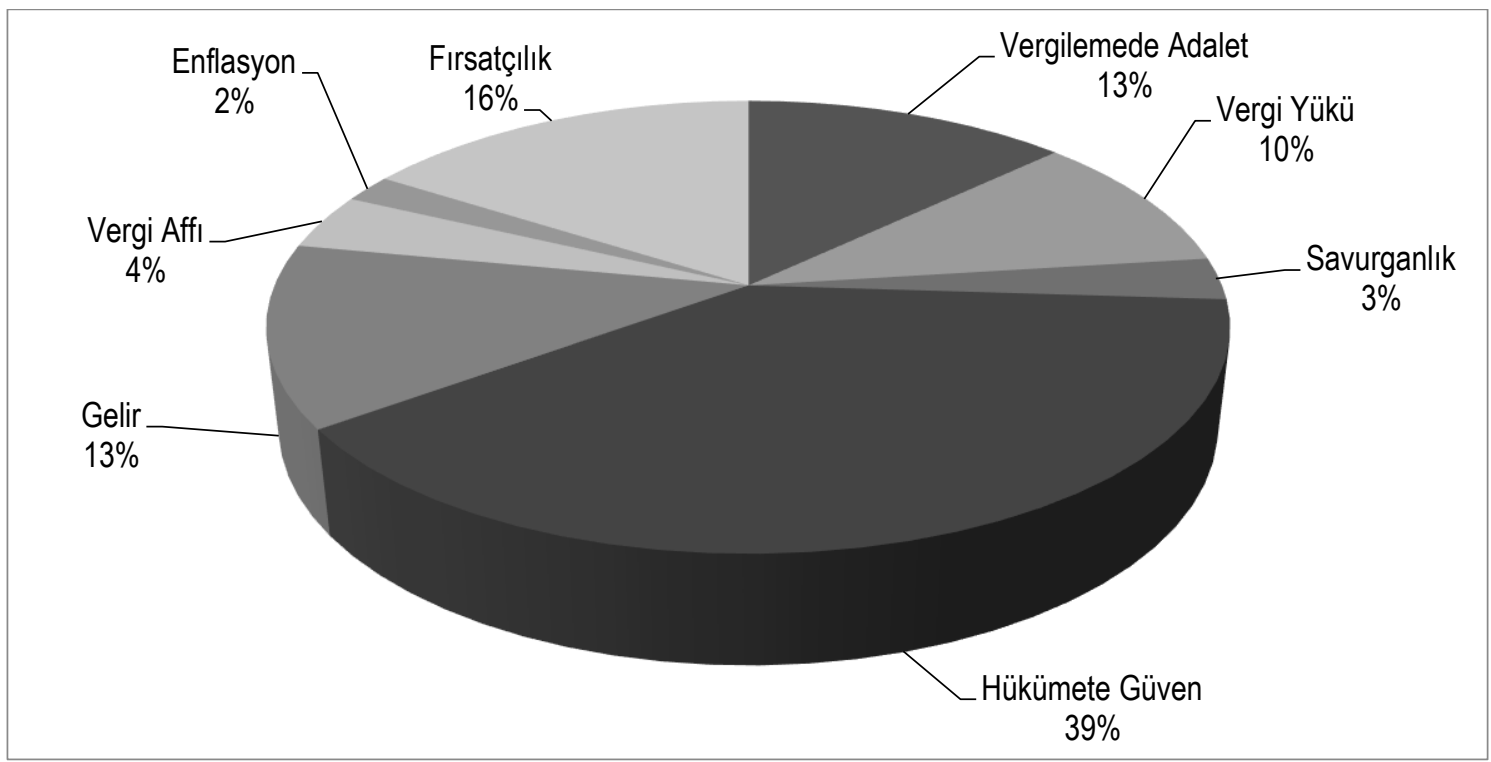

Grafik 1'de analiz edilen 3.990 adet verinin, temalar itibariyle dağılımı gösterilmektedir. Mükellef tepkilerini içeren tweet'lerin $\% 39$ 'u hükümete güven kavramı ile ilişkilendirilir iken \% 16'sı bedelli askerlik talepleri içermesinden dolayı fırsatçılık kavramı ile ilişkilendirilmektedir. MTV ve Gelir Vergisi'nde planlanan değişikliklere ilişkin hazırlanan tasarıya karşı gösterilen tepki tweet'lerinin \%13'ü vergilemede adalet, \%13'ü gelir düzeyleri ile ilgilidir. Tepki gösteren bireylerin \%10'u vergi yükü üzerinden düzenlemeye tepki verirken \%4'ü vergi affı, \%3'ü savurganlık, $\% 2$ 'si Enflasyon ile ilgili tepki vermişlerdir.

\subsubsection{Hükümete Güven}

Birey-devlet ilişkilerinin sağlıklı ve gönüllü uyumun yüksek olabilmesi için bireylerin devlete ait kurum ve kuruluşlarına güven duyması gerekmektedir (Gencel \& Kuru, 2012: 34). Bireylerin devlete duydukları güven duygusu vergi ödeme isteklerini artırmaktadır (Cansız, 2006, Çataloluk, 2008: 219).

Mükellef tepkilerinin \%39 gibi önemli bir kısmı hükümete duyulan güven ile ilişkilidir. Bu konuda atılan tweet'lerin \%95'inden fazlası hükümete karşı olumsuz tepki içermektedir.

Hükümete güvenle ilişkili verilen mükellef tepkilerinin büyük çoğunluğu devlet adamları ve siyasi partiye karşı tepki duymakta iken, bu durumu bir oyun, taktik olarak gören, kendileriyle alay edildiğini düşünen, yönetimsel bir sorun olduğunu öne süren, çok fazlı vergi uygulandığını söyleyen ve yolsuzluk yapıldığını düşünenler de vardır. Az sayıdaki vergi mükellefleri de MTV ve Gelir Vergisi oranlarında yapılması planlanan artışa karşı olumlu bir tavır takınmaktadır. 
Düzenlemeler ile ilgili olarak devlet adamlarına ve siyasi partiye verilen tepkilerden bazıları aşağıda verilmiştir:

"Ya bir başkanın dedikleri 'günde 1 dal sigara içmezseniz veya yılda bir kez ailecek yemeğe gitmezseniz mtv zammını ödersiniz' Bu kadar basit” 2 Ekim 2017, @fatihmurat49

“'MTV müzik televizyonu mu?' diyerek espiri yaptığını sananlar aslında halkla alay etmektedirler.." 2 Ekim 2017, @Siirselyazi

MTV ve Gelir Vergisi oranlarında önce daha yüksek oranda artış yapılıp, daha sonra artışın daha düşük bir orana çekilmesi ile oyun oynandığını öne süren tepkilerden bazı örnekler aşağıda verilmiştir.

"Mtv zammı \%40 diyor, sonra \%20 ye indirilir. Buda çok ama taktik güzel. Buna halk dilinde "ölümü gösterip, sıtmaya razı etmek" denir." 2 Ekim 2017, @demirradammm

“Mtv'de iyi polis kötü polis senaryosunu yeni idrak ediyor halk." 2 Ekim 2017, @mRarmagan

Bahsedilen olumsuz tepkilerin aksine düzenlemelerle ilgili olumlu tepkilere sahip mükellefler de mevcuttur:

"Kutlamalara başlayalım Mtv \%25 Çalışanların maaşından kesilen Gelir Vergisi \%27 olarak ayarlandı. Şükretmeyi öğrenin Mehteri yolluyorum" 13 Ekim 2017, @Seydi55279627

"Etrafımız ateş çemberi küresel sırtlanla savaş halindeyiz savunma harcamaları için mtv artışı gündeme geliyor hayır diyoruz yuh.” 12 Ekim 2017, @ahmetkeserle

\subsubsection{Fırsatçılık}

Kamu tercihi teorisi; metodolojik bireycilik, homo economicus ve politik mübadele varsayımları üzerine kurgulanmıştır. İlk varsayım olan metodolojik bireycilik, kamu ekonomisinde alınan kararların organik birimlerin tercihlerine değil bireylerin tercihlerine dayandığı varsayımıdır. İkinci varsayım, bireylerin homo economicus yani rasyonel davranarak bireysel çıkarlarını maksimize etme anlayışı içerisinde olduklarıdır. Üçüncü varsayım ise, siyasal sürecinin politik bir mübadele olduğu varsayımıdır. Bu varsayıma göre; siyasal süreçte yer alan aktörler tıpkı piyasada alıcı ve satıcı olarak bulunup elmayla portakalı mübadele ederek bireysel faydalarını arttırmaya çalıştıkları gibi, siyasal süreçte de maliyetlerin paylaşımı üzerinde uzlaşarak faydalarını maksimize etmeye çalışırlar (Buchanan, 1987: 244-246).

Kamu tercihi teorisinin varsayımlarına göre, bireylerin rasyonel davranarak bireysel çıkarlarını maksimize etme güdüsüyle hareket ettiklerini ve kamusal konulardaki tutum ve davranışlarını bu doğrultuda şekillendirdiklerini söylemek 
mümkündür. Bu bağlamda, bireylerin vergi ödemeye bakış açıları konjonktürel durumun getirdiği çıkara göre farklılaşabilecektir.

Çalışmada hükümete güvenden sonra \%16 ile vergi artışına karşı mükellef tepkilerinin önemli bir kısmı fırsatçılık kavramı ile ilgilidir. Bireyler bazı durumlarda direkt olarak kendi çıkarını düşünebilmektedirler. MTV ve gelir vergisi artışı yerine bedelli askerliğin kanunlaştırımasına yönelik tepkileri bu verinin önemli bir kısmını oluşturmaktadır.

Bu konudaki mükellef tepkilerinin bazıları şu şekilde sıralanabilir:

“ \%40 lık MTV artışı ile milyonların yükünü arttırmak yerine \#BedelliAskerlik yasasıyla gençlerin kalbini kazanmak daha makul değil mi?” 28 Eylü 2017, @devranspr

"Savunma Sanayi için gelir MTV değil değil VergiYerine BedelliAskerlik ten gelir." 28 Eylü 2017, @Karahanli2018

\subsubsection{Gelir Seviyesi}

Bireyler gelirlerinde azalmaya neden olması bakımından vergilere karşı tepki gösterebilirler. Bu bağlamda, düşük gelir seviyesine sahip mükelleflerin vergi artışları karşısında vereceği tepkiler daha sert olabilecektir (Çataloluk, 2006: 216).

Gelir vergisi tarifesinin üçüncü diliminin oranının \%27den \%30'a yükseltilmesi yönünde hazırlanan tasarı, çalışmakta olan bireyleri doğrudan etkilediğinden, mükelleflerin \%13'ü tarafından tepki ile karşılanmıştır. Gelir Vergisi oranlarındaki artışın Motorlu Taşıtlar Vergisi oranlarında gerçekleşmesi planlanan artıştan daha yüksek bir artış olması ve doğrudan vatandaşların kullanılabilir gelirini etkilemesi gelir yönüyle ortaya çıkan tepkilerin ortak çıkış noktasıdır. Aşağıda gelir seviyesi ile ilgili gösterilen tepkilerden bazı örnekler yer almaktadır:

"Herkes Taşıtlar Vergisi'ne yüklendi ama asıl vurgunu Gelir Vergisi'nde yapmışlar.3-4 ay boyunca her çalışandan ortalama 250 lira kesecekler." 27 Eylül 2018, @SukrettinNizam

“3. Dilimde gelir vergisi \%30 oldu. Asıl vurgun orada, olan gene sabit gelirliye oldu?" 27 Eylül 2018, @KBarbunya

\subsubsection{Vergilemede Adalet}

Vergilemede adalet, kuşkusuz hükümet ve halk tarafından sıklıkla tartışılagelen bir kavramdır. Vergi mükelleflerinin vergi karşında tutum ve davranışlarının belirlenmesinde en önemli etkenlerden birinin adalet olması sebebiyle vergilemede adalet faktörü, vergi uyumunu dolayısıyla mükelleflerin vergiye karşı göstermiş oldukları tepkileri etkileyebilmektedir (Çetin, 2007: 178).

Yapılan analiz sonucunda mükelleflerin \%13'ü adalet kavramı ile vergi oranlarında artış yapılmasına ilişkin düzenlemelere tepki göstermektedir. Araştırma 
kapsamındaki veriler değerlendirildiğinde mükelleflerin adalet algısında; bürokratların ve harcamaları ve lüks makam aracı kullanımları, memur, iş̧̧i ve emekli kesiminin ücret ve maaşlarındaki artışların düşüklüğü, diğer kişi veya kurumların vergi kaçırdıklarına yönelik düşünceler ve vergi afları uygulamalarının etkili olduğu görülmektedir.

$\mathrm{Bu}$ konuda gösterilen tepkilerin dikkate değer bir kısmı çalışan kesim ve emeklilerin ücret ve maaşlarındaki artışların düşük olması üzerinedir:

"Din adına ayda kaç bin lira maaş alsın, sonra çocuklara tacizci olup emekli olsun. Al sana adalet. Artır mtv vergisini para yetmiyor." 10 Ekim 2018, @ AliBayat52350

“insan eleştirilir arkadaş, maaşlara \%3 verenlerin, kalkıp mtv ye \%40 zam yapmasını, hiçbir vicdan sahibi insan kabul etmez" 28 Eylül 2018, @_dean_james

"Şimdiye kadar tespit edilen değerleme oranları üzerinden MTV zammı yapılırken, memur ve emekliye 4+3,5 zamma rağmen \%25'in izahı yoktur." 13 Ekim 2018, @ ikoncuk

Vergi afları mükellef tepkilerine yol açan diğer bir unsurdur:

"Galatasaray, Fenerbahçe, Beşiktaş gibi kulüplerin vergi borçlarını sil, bilmem kaç şirkete vergi affı getir, ama milletin arabasına \%40 MTV" 27 Eylül 2018, @muhammedeminari

\subsubsection{Vergi Yükü}

Vergi yükü, mükelleflerin vergiye yönelik tutum ve davranışlarını etkileyebilmektedir. Vergi yükünün oranı, vergi yükünün adil dağılmadığı düşünceleri mükelleflerin vergilemeye ilişkin tutum ve davranışlarını olumsuz yönde etkileyebilmektedir. Mükellefler; vergi yükünü ödenen vergi ile doğru, vergi ödeme gücü ile ters orantılı olarak hissetmektedirler (Aktan \& Çoban, 2006: 140-141).

Mükelleflerin $\% 10$ 'u verginin üzerlerinde bir yük oluşturduğunu düşündüğünden düzenlemelere karşı gelmektedir. Bu konuda dikkat çekici tepkilerden biri aşağıdadır:

“Araba alsan \%60 vergi Depoyu doldursan \%65 vergi MTV'sini ödesen \%68 vergi Efkarlandım içeyim desen \%70 vergi 2 dal sigara içsen \%82 vergi.." 4 Ekim 2018,

@tezcanbesim

\subsubsection{Vergi Affı}

Hükümetlerin vergi affı uygulamasına sıkça başvurmaları, mükelleflerin af beklentisi sebebiyle ödemeleri gereken vergileri ödemeyi ertelemelerine ya da hiç ödememelerine sebep olmaktadır. Bu durum, hem vergilerini zamanında ödeyen mükelleflerin hem de af beklentisine giren mükelleflerin vergi bilinci ve ahlaklarını 
etkilemekte ve devletin vergi gelirlerinin erimesinden ötürü vergi erozyonu ortaya çıkmaktadır (Öz \& Buyrukoğlu: 89, 93).

Mükellef tepkilerinin vergi affı uygulaması ile ilişkili olanları incelendiğinde, mükelleflerin önemli bir kısmının vergi artışına yönelik düzenlemeler açısından hükümete karşı tepkili olduğu görülmektedir. Mükellefler, hükümetin yanı sıra vergi borçları silinen şirketler ve özellikle futbol kulüplerine de tepki göstermektedir.

Konuyla ile ilgili belirli başı tepkiler şu şekilde gösterilebilir:

"Bazilarinin vergilerini silmeseydik,bugün MTV ye \% 40 zam yapmak zorunda kalmazdik herhalde." 4 Ekim 2018, @mustafasarim

“Telekom, Turkcell, Vodafone'un 5 Milyar USD'lik vergi borcu siliniyor. \%40 MTV artışından elde edilecek 3 Milyar USD'yi savunanlar suskun." 11 Ekim 2018,

@hallederizAS."

\subsubsection{Savurganlık}

Mükelleflerin vergi artışına karşı gösterdiği tepkilerden birini savurganlık teması altında toplamak mümkündür. Mükellefler ödedikleri vergileri kamu harcamalarının karşııı̆ı olarak algılamakta ve bu nedenle yapılan kamu harcamalarına duyarlılık göstermektedir. Kamusal harcamaların toplumun beklentilerini karşılamaması ve yönetimin savurgan olması gibi kötü yönetim uygulamaları mükelleflerin adalet düşüncelerini zedeleyerek vergiye uyumlarını olumsuz yönde etkilemektedir. Mükellefler idare tarafından gereksiz ve lüks harcamaların yapılması, ödedikleri vergilerin toplum yararı yerine geniş halk kitlelerince benimsenmeyen kesimlere aktarılmasını adaletsiz olarak görebilmekte ve devlete olan güvenlerini sarsarak mükellefleri rahatsız edebilmektedir. Bu durum mükelleflerin vergi ödeme motivasyonlarının sübjektif niteliğine işaret etmektedir. Mükelleflerin devlet ve toplumla olan ilişkileri vatandaşların vergi ödeme konusundaki içsel motivasyonlarını, dolayısıyla vergiye uyumlarını etkilemektedir (DPT, 2001: 14; Savaşan \& Odabaş, 2005: 6; Şahpaz \& Saruç, 2012: 67; Tosuner \& Demir, 2007:15; Tunçer, 2002:119).

Mükellef tepkilerinin sadece \%3'ü savurganlık ile ilişkilendirilmiştir. Bu konuda gösterilen tepkilerin neredeyse tamamı olumsuzdur. MTV ve Gelir Vergisi oranlarındaki artışa ilişkin düzenlemelere karşı mükellefler, devletin yaptığı israflara vurgu yapmaktadır. Burada israftan kastedilen kamu sektöründe gerçekleşen lüks harcamalar, makam arabaları, tasarruf eksikliği, proje maliyetleri, örtülü ödeneğin kullanım alanlarıdır. Mükelleflerin yaklaşık \%50'si saray harcamalarına yönelik politik nitelikte tepki göstermektedir. Bu tepkileri, makam araçları üzerinden verilen tepkiler takip etmektedir. Aşağıda bu tepkilerden bazı örnekler verilmektedir:

"Mtv artacağına vekil harcamaları kısıtlansın, vekillerin makam araçları satıısın."

5 Ekim 2018, @Fehmi_Y_ 
“Mtv'ye \%40 zam yapılacağına önce devlet devlet olarak kendi personeline passat vermeyi bırakmalı. Git megane bin neyin eksik? Neyin israfı" 27 Eylül 2018, @DemokrasiGazisi

Mükelleflerin devletin tasarruf eksikliği ile ilişkili gösterdiği bazı tepkiler aşağıdadır:

“Binbir güçlükle alınan vatandaşımızın aracına \%60’ları aşan vergi zammı yapacağınıza önce kendiniz tasarruf yapın. Vergi yükü zaten çok yüksek." 2 Ekim 2018, @akenantanrikulu

Örtülü ödenek ile ilintili mükellef tepkilerde bir örnek ise aşağıda verilmektedir:

“Bu yılın ilk sekiz ayında örtülü ödenek harcamaları, geçen yılın aynı dönemine göre, yüzde 63,1 artarak 2,1 milyar TL'ye ulaştı. Tulumbanın suyu bunun gibi hesapsız harcamalarla bitti." 5 Ekim 2018, @faikoztrak

Sonuç olarak MTV ve Gelir Vergisi tarifesinin üçüncü diliminin oranlarında yapılması planlanan artışa ilişkin düzenlemelere verilen tepkileri savurganlıkla ilişkilendiren mükellef sayısı az olmakla birlikte, mükellefler savurganlığı kamu harcamalarından özellikle saray harcamalarına, kamuda kullanılan makam araçlarına, lüks harcamalara, tasarruf eksikliğine, yap-işlet devret projelerine ve örtülü ödenek harcamalarına bağlamaktadırlar.

\subsubsection{Enflasyon}

Son olarak, mükelleflerin vergi artışı düzenlemeleri sonucu ekonomik güçlerinin ne düzeyde etkileneceği de vergi artışına karşı tepki göstermelerine neden olmaktadır. Türkiye, gelişmekte olan bir ülke olarak yıllar yılı enflasyon ile mücadele etmektedir. Enflasyon sebebiyle geliri enflasyon oranından daha az artan bireyler hayatın daha pahalı olduğunu düşünebilmektedir. Mükelleflerden yalnızca \%3'ü vergi artışına karşılık Enflasyondan bahsetmektedir. Aşağıda bu konu ile ilgili bazı örnekler yer almaktadır:

"Araba alsan \%60 vergi Depoyu doldursan \%65 vergi MTV'sini ödesen \%68 vergi Efkarlandım içeyim desen \%70 vergi 2 dal sigara içsen \%82 vergi." 11 Ekim 2018,

$$
\text { @Huseyin__Taner }
$$

"Halkın geliri \%40 arttı mı ki \%40 zam yapılıyor? Bunu eleştiriyoruz. Vergi olmasın demiyoruz." 27 Eylül 2018, @mgacalov

Araştırma kapsamında elde edilen bulgular ışığında, motorlu taşıtlar MTV ve Gelir Vergisi tarifesinin üçüncü diliminin oranlarında yapılması planlanan artışa ilişkin düzenlemelere yönelik mükelleflerin verdiği tepkilerin önemli bir kısmı hükümete güven kavramı ile ilişkilendirilir iken Enflasyon diğer motivasyon kaynakları ile kıyaslandığında mükellef tepkileri üzerinde daha az etkilidir. 


\section{Sonuç}

Vergilere karşı oluşan tepkiler tarih boyunca birçok sosyal olayın tetikleyicisi olmanın yanında çoğunlukla siyasi iradenin de duyarlı olduğu konular olmuştur. Özellikle teknolojik gelişmelerin hız kazanması da mükelleflerin vergi ile ilgili yapılacak değişikliklere karşı hızlı tepki gösterebilir hale getirmiştir. Ayrıca bu tepkiler sosyal medya aracılığı ile anlık verilebilmekte ve vergi politikalarına karşı alınacak reaksiyonlar bir anda hem siyasi hem de sosyal hayatı etkileyebilir hale gelebilmektedir. Bu duruma en iyi örneklerden bir tanesi de 27 Eylül 2017'de sunulan Motorlu Taşıtlar Vergisi oranında \%40 artış olacağı ve Gelir Vergisi tarifesinin üçüncü diliminin \%27'den \%30'a çıkarılacağı gibi çeşitli düzenlemeler içeren kanun tasarısıdır. Bu tasarı mükellefler tarafından yoğun bir tepki ile karşılaşmıştır. Bu tepkiler sebebiyle 14 Ekim 2017'de alınan kararla MTV oranındaki artış \%25'e çekilmiş, Gelir Vergisi oranlarında ise artış yapılmasından vazgeçilmiştir. Sadece bu sosyal olay bile vergi politikasın etkin uygulanabilmesinde vergilere karşı alınabilecek tepkilerin ve bunları tetikleyen faktörlerin etkin politika uygulanmasında ne derece önemli olduğunu ortaya koyabilir. Literatürde de henüz bu konu hakkında özellikle ülkemiz özelinde bir çalışmaya rastlanamamıştır. Bu nedenle çalışma literatüre vergi artışlarına verilen tepkilerin kaynaklarını anlamak açısından katkı sağlamaktadır.

Mükellef tepkilerini incelemek üzere çalışmada veri kaynağı olarak; gerek toplumun her kesimi tarafından kullanılması, gerek de verilere ulaşılmasının daha kolay olması ve sosyal medya platformu olarak çokça tercih edilen bir mecra olması nedeni ile Twitter, araştırma evreni olarak tercih edilmiştir. Çalışmamı, 27 Eylül-14 Ekim 2017 tarihleri arasında mükelleflerin MTV ve gelir vergisi artışı ile ilgili kanun tasarısı karşısında gösterdikleri tepkilerini ölçmeyi amaçlamıştır. Bu çerçevede toplanan 20.984 adet tweetten 3990 tanesi kullanılabilir bulunmuş ve tematik analiz yöntemi ile nitel analize tabi tutulmuştur. Analiz sonucuna göre vergi artışının, mükelleflerin \%39'u hükümete güven, $\% 16$ 'sı fırsatçılık, \%13'ü mükelleflerin geliri, yine $\% 13^{\prime}$ ü vergilemede adalet, \%10’u vergi yükü, \%4'ü vergi affı, \%3'ü savurganlık, \%2'si hayat pahalılığı ile ilgili olduğu sonucuna ulaşılmaktadır.

$\mathrm{Bu}$ durum, mükelleflerin dikkate değer bir kısmının hükümetin uyguladığı politikalara, aldığı kararlara güven düzeyi ile alakalı olduğu görülmektedir. Karar alıcıların, bireylerin isteklerine ve düşüncelerine daha fazla önem vermesi gerektiği söylenebilir. İkinci olarak bireylerin kendi çıkarlarını umursadığı düşünülürse, bedelli askerlik talepleri doğrultusunda, bireysel çıkar odaklı hareket ettikleri ileri sürülebilir. Özellikle gelir vergisinde artış yapılmasının planlanması ve gösterilen tepkilere dayanarak, vergi konusunda düzenleyici önemlerin alınması ve bazı değişiklikler yapılması gerektiği söylenebilir. Vergilemede adaletin sağlanmasının hükümetlerin birincil amaçlarından biri olduğu düşünüldüğünde, kanun koyucuların daha adil vergilemeye yönelik çalışmalar yapmasının, mükellef tepkilerini etkileyeceği tahmin edilebilmektedir. Hükümetin uyguladığı her verginin, mükellefin vergi yükü algısını etkileyebileceği düşünüldüğünde, devletin ek gelir yaratma konusunda vergiyi daha az 
tercih etme yönünde bir politika izlemesi mükellef tepkilerini etkileyebileceği söylenebilir. Vergi affı konusunda karar alıcılar tarafından izlenecek farklı politikalar, mükellefin hem adalet algısını değiştirebilecek hem de daha az bir vergi yüküne maruz kalmasını sağlayabilecektir. Devletin harcamalarını daha dikkatli yapmaya çalışması, bireylerin hükümete güven düzeyini etkileyebilecektir. Son olarak da fiyat artışlarının azalması bireylerin hükümete duyacağı güven düzeyinde etkili olabilir.

Nihai olarak çalışmamız hükümete duyulan güvenin, vergi artışlarına karşı oluşturulan tepkilerin temel sebeplerinden biri olarak ortaya koymakla beraber bazı kısıtları da mevcuttur. Öncelikle nitel araştırmanın temel kısıtı olan genellenebilirlik bu çalışma için de geçerlidir. Bunun yanında Twitter harici diğer sosyal medya platformları yada görsel içeriği daha ağılıklı olan tweetler tematik analizin doğası gereği analize dahil edilememiştir. Bu nedenle video ya da resim içerikli paylaşımlar analiz dışı kalmıştır.

Vergi artışlarına verilen tepkileri kategorize etmesi ve literaratüre bu alanda yapılan ilk katkılardan biri olmasıyla literatüre sağladığı katkı, ileride bu konuda yapılacak araştırmalar için bir zemin hazırlamaktadır. Ayrıca çalışma bulgularının nicel analizle kısıtlarda belirtilen handikaplarından kurtulmasını ve bahsedilen bulguların genellenebilmesi de takip eden araştırmalarca sağlanabilir.

\section{Kaynakça}

Abdieva, A. P. D. R., \& Cumakunova, T. (2016). “Kırgızistan'da Vergi Bilinci Tax Consciousness in Kyrgyzstan". International Conference On Eurasian Economies, Kaposvár-Hungary, 29-31August 2016.

Akbey, F. (2014). "Türkiye'de Vergi Denetimi ve Gelirleri Üzerine Bir İnceleme”. Dokuz Eylül Üniversitesi İktisadi ve İdari Bilimler Fakültesi Dergisi, No: 29 (1), ss.63103.

Aktan, C. C., \& Çoban, H. (2006). "Vergileme Ekonomisi ve Vergileme Psikolojisi Perspektiflerinden Vergiye Karşı Tutum ve Davranışları Belirleyen Faktörler," Vergileme Ekonomisi ve Vergileme Psikolojisi, (Ed.) Aktan, C. C., Dileyici, D., \& Vural, i. Y., Ankara, Seçkin Yayıncılık, ss. 137-158.

Aktan, C. C., Saraç, Ö., \& Dileyici, D. “Avrupa ve Amerika Tarihinde Vergi İsyanları”, http://docplayer.biz.tr/6981589-Avrupa-ve-amerikan-tarihinde-vergiisyanlari.html.

Albert, F. \& Friedman, J. (1994). "Tax Evasion, Inflation and Stabilization”, Journal of Development Economics, No: 43, ss. 105-123. 
Alkan, A. (2009). "Vergi Bilinci ve Vergi Uygulamaları Karşısında Mükellef Davranışlarının Tespiti: Zonguldak İli Örneği". Yayınlanmamış Yüksek Lisans Tezi, Karaelmas Üniversitesi Sosyal Bilimler Enstitüsü, Zonguldak.

Alm, J. (2010). "Testing Behavioral Public Economics Theories in The Laboratory". National Tax Journal, No: 63 (4), 1-30.

Andreoni, J., Erard, B., \& Feinstein, J., (1998). "Tax Compliance", Journal of Economic Literature, No: 36 , ss. $818-860$.

Barney, J., \& Hesterly, W. (1996). “Organizational economics: Understanding the relationship between organizations and economic analysis", Handbook of Organization Studies, (Ed.) Clegg, S., Hardy, C., \& Nord, W., ss. 115-147.

Bayraklı, H. H., Saruç, N. T. \& Sağbaş, İ. (2004). "Vergi Kaçırmayı Etkileyen Faktörlerin Belirlenmesi Ve Vergi Kaçaklarının Önlenmesi: Anket Çalışmasının Bulguları", 19. Türkiye Maliye Sempozyumu, 10-14 Mayıs 2004, Antalya.

Benk, S., \& Çetin, T. (2010). “Küresel Ekonomik Krizin Vergi Uyumu Üzerindeki Etkileri,” Vergi Dünyası Dergisi, No: 345, ss. 103-116.

Biberoğlu, E. (2006). "Türkiye'de Gönüllü Vergi Uyumu," Yayınlanmamış Yüksek Lisans Tezi, Dokuz Eylül Üniversitesi Sosyal Bilimler Enstitüsü, İzmir.

Boyatzis, R. E. (1998). Transforming Qualitative Information: Thematic Analysis and Code Development, Sage Publications, USA.

Cansız, H. (2006). "Vergi Mükelleflerinin Vergiyi Algılama Hakkındaki Görüşleri: Afyonkarahisar ili Örneği". Afyon Kocatepe Üniversitesi i.i.B.F. Dergisi, No: 8 (2), ss. $115-138$.

Carley, K. M., \& Maxwell, D. (2006). “Understanding Taxpayer Behaviorand Assessing Potential IRS Interventions Using Multiagent Dynamic-Network Simulation", Proceedings of the 2006 Internal Revenue Service Research Conference, Washington, DC, ss. 93-106.

Carver, T. N. (1895). "The Ethical Basis of Distribution and Its Application to Taxation", The Annals of the American Academy of Political and Social Science, Sayı 6, ss. 79-99.

Cuccia, A. \& Carnes, G. A. (2001). "A Closer Look at the Relation Between Tax Complexity and Tax Equity Perceptions," Journal of Economic Psychology, Cilt 22, Sayı 2, s. 113-140.

Çataloluk, C. (2008). "Vergi Karşısında Mükelleflerin Tutum Ve Davranışları", Selçuk Üniversitesi Sosyal Bilimler Enstitüsü Dergisi, No: 20, ss. 213-228.

Çaylı, A. K. (2016). "Asıl Sorunumuz; Oportünizm ya da Fırsatçılık", https://tr.linkedin.com/pulse/as\%C4\%B1l-sorunumuz-oport\%C3\%BCnizm-yada,Yayınlanma tarihi 13 Mayıs 2016. 
Çetin, G. (2007). "Vergi Aflarının Vergi Mükelleflerinin Tutum ve Davranışları Üzerindeki Etkisi," Celal Bayar Üniversitesi iïBF Yönetim ve Ekonomi Dergisi, No: 14 (2), ss. 171-187.

Çetin, T. (2010). “iktisadi Etkinlik Üzerine Bir Deneme: X Etkinlik Yaklaşımı”, Doğuş Üniversitesi Dergisi, No: 11, ss. 183-198.

Çevik, S. (2012). "Mükellefin Devlet ve Toplumla Etkileşimi, Bireysel Normlar ve Vergi Ahlakı", Maliye Dergisi, No: 163, ss. 258-289.

Çiçek, H., Karakaş, M. \& Yıldız, A. (2008). “Güneydoğu Anadolu Bölgesi'nde Vergi Yükümlülerinin Vergiyi Algılama ve Tutum Analizi: Bir Alan Araştırması", Maliye Bakanlığı Strateji Geliştirme Başkanlığı Yayınları, Yayın No: 2008/381, Ankara.

Demir, i. C., \& Küçükilhan, M. (2013). “Vergi Mükelleflerinin Kayıt Dışı Ekonomi Algısı: Türkiye Üzerine Ampirik Bir Çalışma", AïÜ̈-ïBF Ekonomik ve Sosyal Araştırmalar Dergisi, No: 9 (9), ss. 31-48.

Devarajan, S. \& Hossain Shaikh I. (1998); "The Combined Incidence of Taxes and Public Expenditures in Philippines", World Development, No: 26 (6), ss. 963-977.

DPT. (2001). Sekizinci Beş Yıllık Kalkınma Planı Vergi Özel İhtisas Komisyonu Raporu, Ankara.

Duran, i. H. (2001). "Toplum, Devlet ve Vergi Sorunları," Vergi Sorunları, No: 153, ss. 73-75.

Edgeworth, F. Y. (1897). "The Pure Theory of Taxation". The Economic Journal, No: 7 (28), ss. $550-71$.

Edizdoğan, N., \& Gümüş, E. (2013). "Vergi Afları ve Türkiye'de Vergi Aflarının Değerlendirilmesi". Maliye Dergisi, No: 164, ss. 99-119.

Öz, E., \& Buyrukoğlu, S. (2011). “Cumhuriyet Tarihinde Vergi Afları: Maddi ve Manevi Erozyonlar". Vergi Sorunları Dergisi, No: 272, ss. 89-104.

Ersoy, A. F., \& Öztürk, F. (2015). "Bir Vatandaşlık Değeri Olarak Yurtseverlik: Sosyal Bilgiler Öğretmen Adaylarının Algısı". İlköğretim Online, No: 14 (3), ss. 974-992.

Friedland, N., Maital, S., \& Rutenberg, A. (1978). "A simulation study of income taxation", Journal of Public Economics, No: 10, ss.107-116.

Gencel, U., \& Kuru, E. (2012). "Vergi Kültürü ve Vergi Politikaları Etkileşimi: Türkiye Değerlendirmesi", Çanakkale Onsekiz Mart Üniversitesi Yönetim Bilimleri Dergisi, No: 10 (20), 29.

Ghoshal, S., \& Moran, P. (1996). “Bad for Practice: A Critique of The Transaction Cost Theory", Academy of Management Review, No: 21, ss. 13-35.

Gök, M., Biyan, Ö., \& Akar, S. (2013); "Vergilemede Adalet İlkesinin Anayasal Temelleri ve Uygulamaya Yansımaları: Seçilmiş OECD Ülkeleri Açısından Karşılaştırmalı Bir Analiz", Marmara Üniversitesi iiBF Dergisi, No: 34 (1), ss. 269-292. 
Gökalp, N. (2003). "Ekonomide Güven Faktörü". Yönetim ve Ekonomi: Celal Bayar Üniversitesi İktisadi ve İdari Bilimler Fakültesi Dergisi, No: 10 (2), ss. 163-174.

Gönüllü, A. R. (2015). "Milli Mücadele ve Cumhuriyet Döneminde Hayvanlar Vergisi (1920-1962).", Selçuk Üniversitesi Türkiyat Araştırmaları Dergisi, No: 38, ss. 69102.

Graetz, M. J., \& Wilde, L. L. (1985). "The Economics of Tax Compliance: Fact and Fantasy", National Tax Journal Social Science Working Paper 574.

Graf Lambsdorff, Johann(2005); "Consequences and Causes of Corruption: What Do We Know from a Cross-Section of Countries?", University o Passau Faculty of Business and Economics, ss. 1-35.

Gürler Hazman, G. (2009). "Vergi Bilincini Etkileyen Muhtemel Dışsal Etkenlerin Lojistik Regresyon Analizi ile Tespiti". Akademik İncelemeler Dergisi, No: 4 (1), ss. 5371.

Hanousek, J. \& Palda, F. (2004). "Quality of Government Services and the Civic Duty to Pay Taxes in the Czech and Slovak Republics, and other Transition Countries," International Review for Socail Sciences, No: 57 (4), ss. 237-252.

Hite, P. A. (1997). "Identifying and Mitigating Taxpayer Non-compliance," Australian Tax Forum, No: 13, 155.

İzgi Şahbaz, K., \& Saruç, N. T. (2012). "Vergi Ahlakını Etkileyen Faktörler: Sakarya Üniversitesi Örneği", Sakarya İktisat Dergisi, ss. 57-81.

İzgi Şahpaz, K. ve Saruç, N. T. (2011). "Sosyo-Kültürel Faktörlerin Vergi Ahlakı Üzerindeki Etkisi: Üniversite Öğrencileri ile Yapılan Anket Çalışması", Ekonomi Bilimleri Dergisi, Cilt 3, Sayı 2, ss.57-81.

Kaynar Bilgin, H. (2011). "Türkiye'de Vergi Ahlakının Belirleyicileri”, ODTÜ Gelişme Dergisi, No: 38, ss. 167-190.

Kirchler, E., Hoelzl, E., \& Wahl, I. (2008). “Enforced versus Voluntary Tax Compliance: The "Slippery Slope" Framework", Journal of Economic Psychology, No: 29 (2), ss. $210-225$.

Konrad, K. A., \& Qari, S. (2012). "The Last Refuge of a Scoundrel? Patriotism and Tax Compliance", Economica, No: 79 (315), ss. 516-533.

Kotlikoff, L. \& Summers, L. (1987). "Tax Incidence", National Bureau of Economic Research, ss.1043-1092.

Martinez-Vazquez, J., \& Torgler, B. (2009). "The Evolution of Tax Morale in Modern Spain", Journal of Economic Issues, No: 43 (1), ss. 1-28.

Melgar, N., \& Rossi, M., \& Smith, T. W. (2010). "The Perception of Corruption", International Journal of Public Opinion Research, No: 22 (1), ss. 120-131.

Morgan, R. M., \& Hunt, S. D. (1994). "The Commitment-Trust Theory of Relationship Marketing", Journal of Marketing, No: 58, ss. 20-38. 
Muter, N., Sakınç, S., \& Çelebi A. K. (1993). “Mükelleflerin Vergi Karşısındaki Tutum ve Davranışları Araştırması", Celal Bayar Üniversitesi iỉBF Maliye Bölümü Yayınları, Manisa.

Ömürbek, N., Çiçek, H. G., \& Çiçek, S. (2007). "Vergi Bilinci Üzerine Bir İnceleme: Üniversite Öğrencileri Üzerinde Yapılan Anketin Bulguları," Maliye Dergisi, No: 153, Temmuz-Aralık, ss. 102-122.

Rawls, J. (1921). "A Theory of Justice", Revised Edition, The Belknap Press of Harvard University Press Cambridge, Massachusetts.

Richardson, G. (2006). "Determinants of tax evasion: A cross-country investigation," Journal of International Accounting, Auditing and Taxation, 15

Ritsema, C. M. (2001). "Economic and Behavioral Chara Cteristics of Noncompliant Taxpayers: Evidene From The 1997 Arkansas Tax Penalty Amnesty Program," University of Arkansas.

Savaşan, F., \& Odabaş, H. (2005). Türkiye'de Vergi Kayıp ve Kaçaklarının Nedenleri Üzerine Ampirik Bir Çalışma, Selçuk Üniversitesi iiBF Sosyal ve Ekonomik Araştırmalar Dergisi, No: 10, ss. 1-28.

Schmölders, G. (1960). Das Irrationale in der o" ffentlichen Finanzwirtschaft. Frankfurt am Main: Suhrkamp.

Serim, N. (2015). “Gönüllü Vergi Uyumunu Arttırmada Kamu Otoritesinin Düzenleyici Rolünün Ve Mükellef Çevresinin Önemi: Sıralı Probit Model Yaklaşımı”, AKÜ IiBF Dergisi- No: XVII (1), ss. 141-156.

Stiglitz, J. E. (1986). "The general theory of tax avoidance", National Bureau of Economic Research Cambridge, Massachusetts, USA.

Stiglitz, J. E. (1988). "Tax Reform, Theory and Practice", The Economics of Tax Reform, W.E. Upjohn Institute Press for Employment Research, Princeton University,

Şen, H., \& Sağbaş, ì. (2015). Vergi Teorisi ve Politikası, Ankara.

Şenyüz, D. (1995). Vergilemede Yükümlü Psikolojisi, Bursa: Ekin Yayınevi.

Şenyüz, D. (2014). "Hukuk Devleti Perspektifinden Adil Vergileme ve Vergi Afları". TESAM Akademi Dergisi, No: 1 (2), ss. 81-96.

Tanzi, V. (1998). Corruption Around the World: Causes, Consequences and Cures, International Monetary Fund Fiscal Affairs Department WP/98/63, ss. 1-39.

Tanzi, V., \& Dovoodi, H. R. (2000). Corruption, Growth and Public Finances, International Monetary Fund WP 00/182, ss.1-27.

Taytak, M. (2016). “Vergi Kültürünü Belirleyen Faktörler ve Mükelleflerin Demografik Özelliklerinin Vergi Kültürü Üzerindeki Etkisi", Journal of the Human and Social Sciences Researches.

TDK, Türk Dil Kurumu Büyük Sözlüğü. http://www.tdk.gov.tr/index.php?option=com_bts 
Tezcan, M. (1985). Eğitim Sosyolojisi, Ankara Üniversitesi Eğitim Bilimleri Fakültesi Yayınları No: 150, Ankara.

Torgler, B., \& Murphy, K. (2004). "Tax Morale in Australia: What Shapes It and Has It Changed Over Time ?," Journal of Australian Taxation, No: 7 (2), ss. 298-335.

Torgler, B. (2003). "Tax Morale and Institutions". Basel:CREMA Working Paper No: 9, ss. 1-36.

Torgler, B. (2004). "Tax Morale in Asian Countries", Journal of Asian Economics, No: 15, ss. 237-266.

Taytak, M. (2016). "Vergi Kültürünü Belirleyen Faktörler ve Mükelleflerin Demografik Özelliklerinin Vergi Kültürü Üzerindeki Etkisi", İnsan ve Toplum Bilimleri Araştırmaları Dergisi-Journal of the Human and Social Science Researches, 5(7), 1933-1957.

Torgler, B., \& Murphy, K. (2004). "Tax morale in Australia: What shapes it and has it changed over time?", Journal of Australian Taxation, No: 7(2), ss. 298-335.

Torgler, B., \& Schneider, F. (2006). What Shapes Attitudes Toward Paying Taxes? Evidence From Multicultural European Countries. Germany: IZA Discussion Paper, No: 2117.

Tuay, E., \& Güven, ì. (2007). “Türkiye'de Mükelleflerin Vergiye Bakışı," Gelir İdaresi Mükellef Hizmetleri Daire Başkanlığı, Yayın No: 51.

Tunca, E. (2011). "Sosyo-Psikolojik Açıdan Vergi Mükelleflerinin Vergi Karşısındaki Tutum Ve Davranışları (Nevşehir ili Örneği) " Yayınlanmamış Yüksek Lisans Tezi, Süleyman Demirel Üniversitesi Sosyal Bilimler Enstitüsü, Isparta.

Tunçer, M. (2002). "Hükümet-Birey iliş̧kilerinin Vergi Uyumuna Etkisi ve Türkiye," Ankara Üniversitesi SBF Dergisi, No: 57 (3), ss. 107-128.

Turan, D. \& Yurdakul, A. (2014). "Geçiş Ülkelerinde Vergi Ahlakı". Business and Economics Research Journal, No: 5 (1), ss. 123-141.

Turhan, S. (1998). Vergi Teorisi ve Politikası, 6. Baskı, İstanbul: Filiz Kitabevi.

Vogel, J. (1974). "Taxation and Public Opinion in Sweden: An Interpretation of Recent Survey Data", National Tax Journal, ss. 499-513.

Williamson, O. E. (2005). "Transaction Cost Economics", Handbook of New Institutional Economics, (Ed.), Menard, C., Shirley, M., Netherlands: Springer.

Williamson, O. E. (1985). The Economic Institutions of Capitalism. New York: Free Press.

Witte, A. D., \& Woodbury, D. F. (1985). "The Effect of Tax Laws and Tax Administration on Tax Compliance: The Case of the U.S. Individual Income Tax," National Tax Journal, ss. 1-13.

Yaraşır, S. (2013). "Vergi Afları Ve Türkiye'deki Vergi Aflarının Değerlendirilmesi", Vergi Dünyası, No: 379 (2013), ss. 175-187. 
Yaraşı, G. O. (2005). "Türkiye'de Vergi Reformu", Maliye Bakanlığı Yayınları, Ankara.

Yenal, Ö. (2001). "Gelir Vergisinin Vergi Güvenliği Açısından Değerlendirilmesi," i.ü. íktisat Fakültesi Maliye Araştırma Merkezi Konferansları 39. Seri, İstanbul.

Yeniçeri, H. (2004). "Beyan Esasına Dayanan Vergilerde Vergi Kayıp ve Kaçaklarının Psikolojik Nedenlerinin Tespitine Yönelik Bir Araştırma", 19. Türkiye Maliye Sempozyumu, 10-14 Mayıs 2004, Antalya.

Yeniçeri, H. (2005). Vergi Yükümlülerinin Vergi Karşısındaki Tutum ve Davranışlarının Gelir Düzeyine Göre Karşılaştırılması. Sosyoloji Konferansları, No: 31, ss. 279299.

Yeniçeri, H., \& Çevik, S. (2014). "Sosyal ve Politik Etkileşim, Bireysel Değerler ve Vergi Ahlâkı Arasındaki İlişkilerin Yapısal Eşitlik Modeli ile Test Edilmesi". Amme İdaresi Dergisi, No: 47 (3).

Yereli, A. B., \& Ata, A. Y. (2011). "Vergi Adaletine Ulaşma Yöntemleri Çerçevesinde Fayda Illkesinin Teorik Açıdan Değerlendirilmesi". Maliye Dergisi, No: 161, ss.2132.

Yılmaz, E. (1992). Hukuk Sözlüğü, 4.Baskı, Ankara: Yetkin Hukuk Yayınları.

Yüce, M. (2004). “Kırgizistan'da Mükelleflerin Vergi Kaçıranlara Bakışı”. Akademik Bakış Dergisi, ss. 1-11.

Zenginobuz, Ü., Adaman, F., Gökşen, F., Savcl, Ç., \& Tokgöz, E. (2010). "Vergi, Temsiliyet ve Demokrasi îlişkisi Üzerine Türkiye'de Vatandaşların Algıları", Açık Toplum Vakfı Yayınları, İstanbul. 